\title{
Investigating the Role of MODIS Leaf Area Index and Vegetation-Climate Interaction in Regional Climate Simulations over Asia
}

\author{
Jingyong Zhang ${ }^{1,2,}$, Dong-Hyun Cha ${ }^{1}$, and Dong-Kyou Lee ${ }^{1}$ \\ ${ }^{1}$ Atmospheric Sciences Program, School of Earth and Environmental Sciences, Seoul National University, Seoul 151742, Korea \\ ${ }^{2}$ START/TEA, Institute of Atmospheric Physics, Chinese Academy of Sciences, Beijing 100081, China
}

Received 1 August 2007, accepted 3 April 2008

\begin{abstract}
Four yearlong climate simulations using the Seoul National University, regional climate model have been performed to assess the role of the MODIS Leaf Area Index (LAI) and interactive LAI in influencing Asian climate. The control experiment employs the fixed monthly LAI according to the original land surface model. Another additional simulation replaces the LAI by 4-year mean MODIS climatology. The last two integrations both allow the LAI to interact with the atmosphere, but adopt two different simple parameterization schemes.

Although the control experiment generally reproduces spatial distribution and the magnitude of Asian surface climate, it contains large biases in some specific areas, which are partly improved by the implementation of MODIS LAI and vegetation interaction schemes. In winter months (January-to-March), greener land surface introduced in the last three simulations reduces cold biases over Northeast China and adjacent areas, southern China, Korea, and Japan, and warm biases over South Asia, and precipitation discrepancies over South Asia, southern China and West Japan. In contrast, LAI changes only play a limited role in summer. There are significant differences between regions with respect to mechanisms explaining winter-month improvement in surface climate simulations. Over Northeast China and adjacent areas, increased LAI increases net solar radiation by about $12 \mathrm{~W} \mathrm{~m}^{-2}$ mainly through the effects on surface albedo, thereby warming the surface by about $1.8^{\circ} \mathrm{C}$. A decrease in clouds makes a major contribution to surface warming and precipitation reduction over southern China. Increased evapotranspiration dominates changes in surface energy balance, and cause less net radiation to be partitioned into sensible heat over South Asia. As a result, the model simulates about $1.5^{\circ} \mathrm{C}$ colder surface air temperature and about $0.1 \mathrm{~mm} \mathrm{day}^{-1}$ more precipitation over this region. Finally, the implications and limitations of this study are also discussed.
\end{abstract}

Key words: Leaf area index, Vegetation-climate interaction, Regional climate model

Citation: Zhang, J., D. H. Cha, and D. K. Lee, 2009: Investigating the role of MODIS leaf area index and vegetation-climate interaction in regional climate simulations over Asia. Terr. Atmos. Ocean. Sci., 20, 377-393, doi: 10.3319/TAO.2008.04.03.01(A)

\section{INTRODUCTION}

The role of the terrestrial system in influencing climate has been increasingly recognized in past thirty years. Recent statistical analyses to available observations indeed demonstrated evidence for land surface feedbacks on surface climate (Kaufmann et al. 2003; Zhang et al. 2003, 2008; Liu et al. 2006; Wang et al. 2006). However, because the physical and dynamical mechanisms involved definitely cannot be extracted statistically, models are still the major tool for understanding land-atmosphere interactions with

\footnotetext{
* Corresponding author

E-mail:zjy@climate.cestm.albany.edu
}

their additional capacity for process and causality analyses.

In models, a realistic description of land surface-atmosphere interactions involving complex physical and chemical processes requires accurate specification of many land surface parameters. The Leaf Area Index (LAI), i.e., one sided green leaf area per unit ground area for broadleaf canopies or projected needle-leaf areas for coniferous canopies, has been identified as one key parameter.

Atmospheric General Circulation model (AGCM) studies have found that LAI changes play an important role in simulations of near-surface climate patterns and changes (e.g., Chase et al. 1996; Maynard and Royer 2004). For ex- 
ample, Buermann et al. (2001) demonstrated that the utility of LAI data derived from the maximum NDVI of Advanced Very High resolution Radiometer Pathfinder (AVHRR) data could improve global surface climate simulations. With the launch of TERRA carrying the Moderate Resolution Imaging Spectroradiometer (MODIS) onboard, global or regional high-quality LAI fields from MODIS-measured canopy reflectance data could now be provided (Knyazikhin et al. 1998; Myneni et al. 2002; Tian et al. 2004; Yang et al. 2006). A more accurate representation of the LAI field using MODIS data may contribute to an improvement in climate simulations.

Climate is the most important driving force in shaping natural vegetation growth and distribution. However, earlier models only described one-way vegetation feedback through predefined vegetation phenology, which limited response of vegetation to climate anomalies, such as warmer or colder than average seasons or years, or to long-term changes in climate. In the past decade, some land surface model groups have been motivated to develop global coupled vegetation-climate interaction models, for instance, Foley et al. (1998), and Delire et al. (2002). Simulations of present climate and Paleoclimate using these coupled models suggested the importance of vegetation interactions (e.g., Texier et al. 1997; Bonan et al. 2003; Delire et al. 2004; Levis and Bonan 2004; Arora and Boer 2006). Regarding regional studies, Lu et al. (2001) demonstrated that seasonal changes of vegetation strongly influence regional climate patterns over the central United States. Tsvetsinskaya et al. (2001) introduced daily plant growth into a regional climate model, and found that surface heat, moisture, and momentum fluxes are sensitive to interactively simulated LAI and canopy height over the central Great Plains. Zeng et al. (1999), and Wang and Eltahir (2000) concluded that vegetation-climate interactions enhance the low-frequency variability of climate over the Sahel while suppressing the high-frequency variability.

Over Asia, the complex topography and large vegetation gradient are able to induce meso-scale circulations strong enough to modify synoptic circulation and form local climates. Compared with AGCMs, regional climate models (RCMs) are more skillful at resolving land surface heterogeneity and other physical processes, and thus may better reproduce Asian regional climate variation and variability (e.g., Leung et al. 1999; Wang et al. 2003; Fu et al. 2005; Ding et al. 2006). However, most previous RCM studies of Asian climate generally only included one-way vegetation feedback. Chen et al. (2004) showed the importance of incorporating interactive vegetation in simulating East Asian climate and climate change due to atmospheric $\mathrm{CO}_{2}$ using regional coupled soil-vegetation-atmosphere model simulations.

The objective of the present study is to examine the feasibility of using MODIS LAI and simple vegetation- climate interaction schemes to improve seasonal Asian climate simulation in the Seoul National University, Regional Climate Model (SNU-RCM). We focus on seasonal changes in LAI, which is different with previous RCM simulations of East Asia climate by Chen et al. (2004) that used an equilibrium vegetation model to examine vegetation interaction effects on long-term mean climate and climate change. In current land surface models, vegetation phenology is parameterized mainly using prescribed monthly vegetation parameters (e.g., BATS: Dickinson et al. 1993), the prescribed threshold temperature or simple functions of temperature (e.g., IBIS: Foley et al. 1996), the degree-day and chillingday sum[s] (e.g., BIOME3: Haxetline and Prentice 1996; LPJ: Bonan et al. 2003), and the carbon benefit and loss approach (e.g., FBM: Lüdeke et al. 1994). In this study we use two vegetation interaction schemes to represent the response of vegetation to seasonal climate variations: one is based on regression equations, and the other follows the simple dynamic vegetation model in Zeng et al. (1999).

The paper is organized as follows. Section 2 describes model and experiment design as well as processes affected by LAI changes. Section 3 presents the responses of surface climate and associated surface energy balance and atmospheric circulation to the implemented MODIS LAI and two vegetation interaction schemes. Finally, conclusion and discussion are given in section 4 .

\section{APPROACH}

\subsection{The Regional Climate Model}

The Seoul National University, Regional Climate Model (SNU-RCM) (Lee et al. 2002, 2004) is employed in this study. The atmospheric component is based on the FifthGeneration NCAR/Penn State Mesoscale Model (MM5) (Grell et al. 1994), a non-hydrostatic primitive equation model written in terrain-following sigma coordinates and originally developed for medium-range forecasting. To simulate long-term surface processes, an advanced and comprehensive land surface parameterization scheme, the NCAR land surface model (NCAR/LSM) (Bonan 1996), has been implemented into the SNU-RCM (Kang et al. 2005).

The NCAR/LSM is a one-dimensional model of energy, momentum, water and $\mathrm{CO}_{2}$ exchange between the land and the overlying atmosphere. It solves the surface energy budget, taking into account ecological differences among vegetation types, hydraulic and thermal differences among soil types, and allowing for multiple plant types (up to three) within a vegetated model grid cell. Vegetation effects are included by allowing for 13 functional plant types that differ in plant physiology (leaf optical properties, stomatal physiology, leaf dimension) and vegetation structure (height, roughness length, displacement height, root profile, and monthly leaf and stem area). The 13 functional plant types are combined with the bare ground to give 28 different vege- 
tated surfaces. The model evaluates surface fluxes at every time step (20 min in this study) and for each sub-grid cell independently, using the same grid-averaged atmospheric forcing. It then provides the grid-averaged surface fluxes to the atmospheric model by taking the sub-grid fractional areas into consideration.

\subsection{Experiment Design}

Four experiments are preformed over the period of 1 January to 31 December 1998. All the model configurations are the same in these experiments except for LAI and the changes due to LAI. We refer to the four simulations as: (a) control experiment (CTL); (b) experiment with MODIS LAI (MODIS); (c) experiment with LAI calculated with the regression equations (ReDVM); and (d) experiment with a simple dynamic vegetation model (SiDVM).

The CTL employs prescribed biome-specific monthly LAI, which is originally used in the NCAR/LSM. The LAI in each vegetated model grid cell is calculated using 13 LSM LAI profiles (Fig. 1).

The MODIS replaces the LSM profiles with the MODIS climatic ones (Fig. 1). The MODIS product quality and its consistency with field measurements were improved in
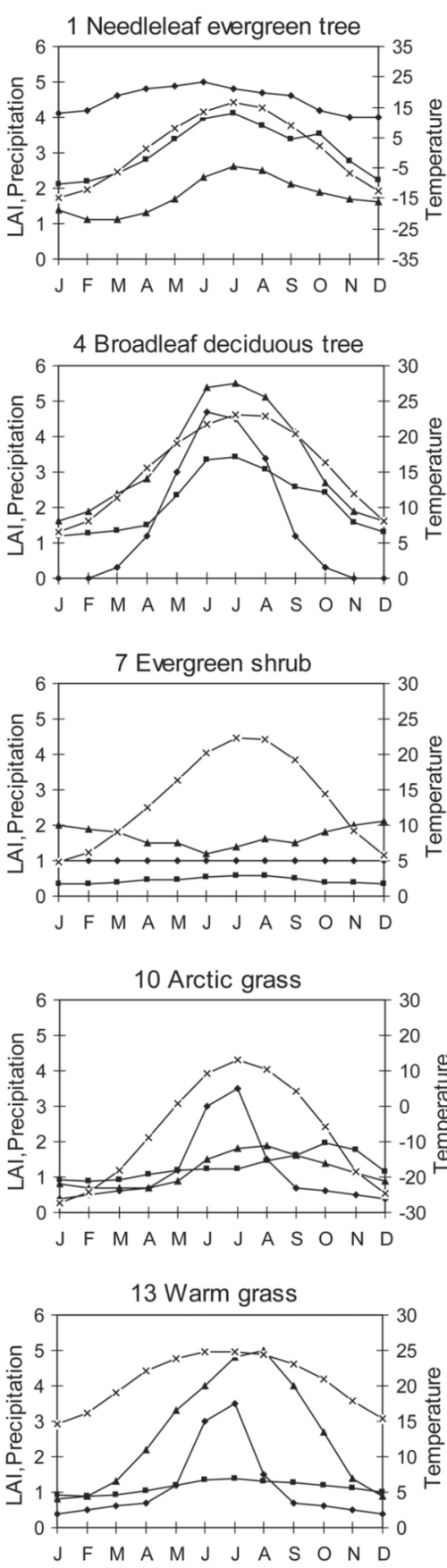

$\rightarrow$ LSMLAI

$\rightarrow$ MODIS LAI

$\rightarrow$ Precipitation

$-x-$ Temperature
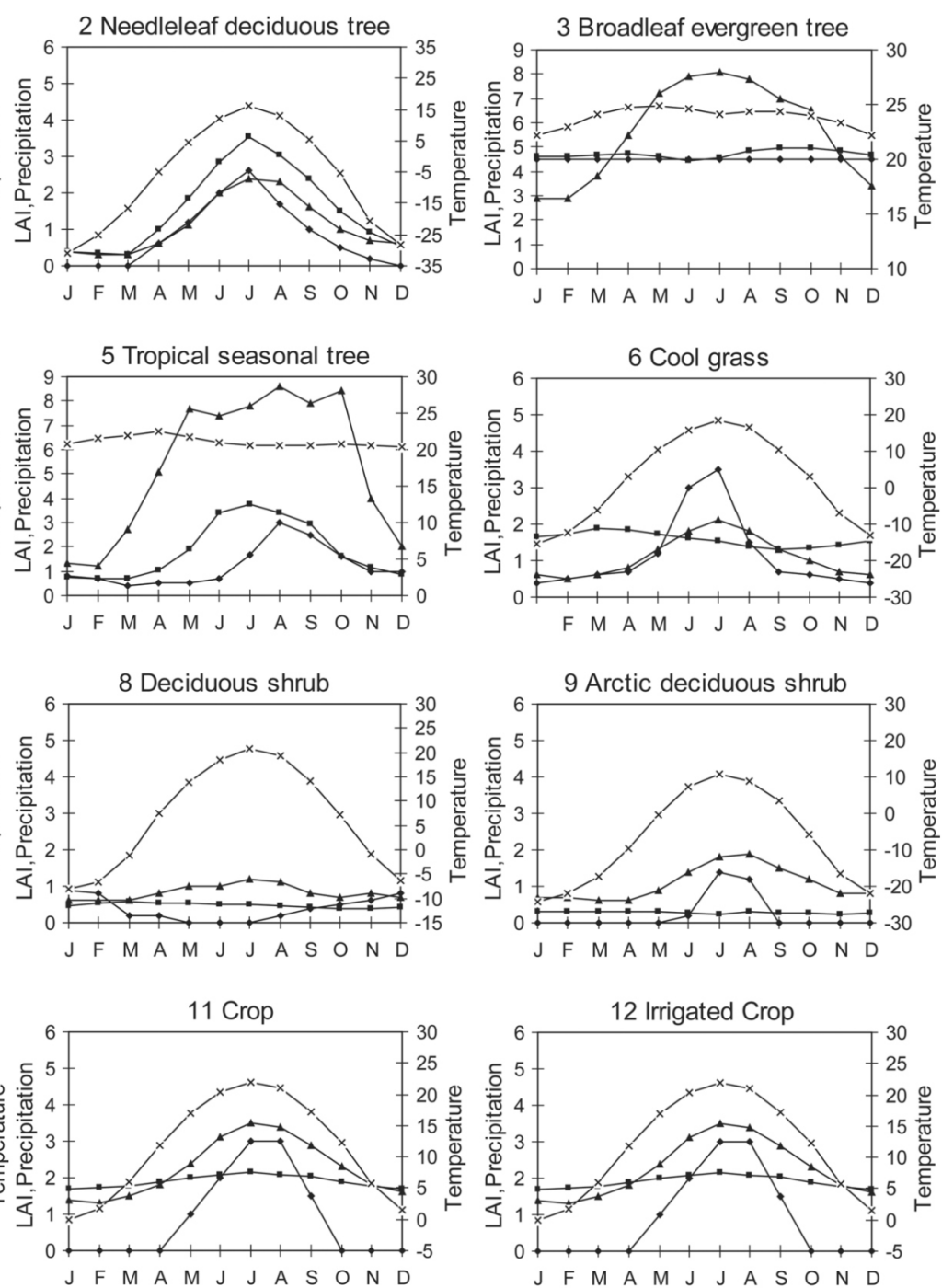

Fig. 1. NCAR/LSM and MODIS LAI profiles, and precipitation (in $\mathrm{mm} \mathrm{day}^{-1}$ ) and temperature (in ${ }^{\circ} \mathrm{C}$ ) from Willmott and Matsuura (1995) for 13 vegetation types. 
Collection 4 compared with previous version by incorporating substantial changes in the algorithm and its inputs (e.g., Yang et al. 2006). The $4 \times 4 \mathrm{~km}$ MODIS data for the period from July 2000 to June 2004 were first averaged to produce the climatic LAI field. The climatic data over the Northern Hemisphere were then aggregated to obtain the MODIS LAI profiles for 13 LSM vegetation types using the MODIS biome map (Myneni et al. 2002) and latitudinal information.

In the ReDVM, the regression equations between the monthly mean temperature and the MODIS LAI are developed to predict the response of vegetation to climate variations (Table 1). With dynamic vegetation enabled, LAI is simulated rather than obtained from prescribed surface datasets. Here we mainly consider vegetation types with large seasonal changes in LAI, which generally exhibit a strong response to surface air temperature.

In the last experiment, a simple dynamic vegetation model, which follows the vegetation interaction scheme in Zeng et al. (1999), is implemented into the SNU-RCM. We focus on the response of vegetation phenology, and use surface air temperature to predict the daily LAI of forest and grass, respectively. The central equation in the simple model is a biomass equation driven by photosynthesis and vegetation loss:

$\frac{d L}{d t}=\alpha \gamma(T)\left(1-e^{-k L}\right)-\frac{L}{\tau}$

Where $L$ is leaf area index, $\alpha$ is a carbon assimilation coefficient, $T$ is surface air temperature, $\gamma(T)$ is an empirical parameter depending on $T$, and $k$ is the extinction co- efficient of photosynthetically active sunlight taken as 0.75 (Zeng et al. 1999). $\tau$ is the leaf growth timescale, depending on climate, vegetation and soil properties. Here, we take 15 and 10 days for forest and grass/crop, respectively. $\alpha$ is calculated as follows:

$\alpha=\frac{L_{w}}{\tau\left(1-e^{-k L_{w}}\right)}$

where $L_{w}(=8)$ is an optimal leaf area index based on the observation. If $\gamma(T)$ is dependent on surface air temperature, we can arrive at a linear relation, based on MODIS LAI and temperature from Willmott and Matsuua (1995):

$\gamma(T)=(T-215) / 215$

15 and 10-day running mean $T$ are used to calculate $\gamma$ values for forest and grass/crop, respectively.

The model domain consists of $151 \times 111$ grid points with a horizontal grid spacing of $60 \mathrm{~km}$, including nearly all areas over Asia and nearby oceans. There are 23 layers in the vertical direction with the model top at $70 \mathrm{hPa}$. Other physical parameterizations used in this study include AnthesKuo's cumulus scheme (Anthes 1977), the simple ice explicit moisture scheme (Dudhia 1989), non-local planetary layer physics (Hong and Pan 1996), and the NCAR Community Climate Model version 2 (CCM2) radiation package (Briegleb 1992).

The 6-hourly NCEP/NCAR reanalysis-II data (Kistler et al. 2001) and the observed sea surface temperature updated every 24 hours from Smith and Reynolds (1998) are interpolated to model grids to provide initial and lateral

Table 1. Regression equations of LAI with surface air temperature.

\begin{tabular}{ccc}
\hline LSM vegetation type & \multicolumn{1}{c}{ Regression equation } & $\boldsymbol{R}^{2}$ \\
\hline 1 & $L A I=0.0605 T+2.995$ & 0.9322 \\
2 & $L A I=1.5556 e^{0.049 T}$ & 0.8615 \\
4 & $L A I=0.7371 e^{0.0635 T}$ & 0.9172 \\
11,12 & $L A I=0.0002 T^{2}+0.014 T+1.6915$ & 0.9902 \\
13 & $L A I=0.5434 e^{0.035 T}$ & 0.7327 \\
\hline
\end{tabular}


boundary conditions for driving the regional climate model. The buffer zone in the lateral boundaries consists of 15 grid points. A linear-exponential combined formula is adopted to determine nudging coefficients (Liang et al. 2001). Initial soil moisture and temperature data required for SNU-RCM are obtained from an off-line simulation of NCAR/LSM, after it reaches an equilibrium state under the forcing of 6-hourly atmospheric values, and surface radiation from NCEP/NCAR reanalysis, as well as daily precipitation data from the NCEP/CPC archives.

\subsection{Physical Processes Affected by LAI Changes}

Land surface determines the partitioning of surface net energy $\left(R_{n}\right)$ into sensible heat $(H)$ to warm the near-surface atmosphere, latent heat $(\lambda E)$ released to fuel precipitation at higher levels, ground heat $(G)$ to warm the soil, and snow melt heat $(M)$ :

$R_{n}=H+\lambda E+G+M$

where $R_{n}$ is calculated as:

$R_{n}=S \downarrow\left(1-\alpha_{s}\right)-(L \uparrow-L \downarrow)$

where $S \downarrow$ is solar radiation reaching the Earth's surface, $\alpha_{s}$ is surface albedo determining reflected solar radiation, and $L \uparrow$ and $L \downarrow$ are emitted and received longwave radiation by the surface. An increase in LAI directly decreases $\alpha_{s}$ of the vegetated land surface, and therefore increases $R_{n}$. Increased LAI can also increase plant transpiration by increasing stomatal conductance under optimal growing conditions, and increase canopy evaporation by intercepting more precipitation during rainy days. This will subsequently affect the partitioning of $R_{n}$ into $H$ and $\lambda E$. Except for surface energy budget, a change in LAI can also influence surface water balance mainly through canopy evaporation and transpiration. Modification of surface energy and water processes will further transfer into anomalies in the atmospheric boundary layer, clouds, precipitation, and circulations, which in turn enhance or damp surface energy and water cycles.

\section{RESULTS}

\subsection{Differences in LAI}

Figure 2 shows the LAI difference fields between MODIS, ReDVM, SiDVM and CTL in winter and early spring (January-to-March), and summer (June-to-August). The MODIS LAI for each LSM surface type is generated using $4 \times 4 \mathrm{~km}$ data and was shown earlier (Fig. 1). In ReDVM and SiDVM, the LAI is predicted by surface air temperature. LAI changes are similar in spatial structure in MODIS, ReDVM and SiDVM. In most areas of the model domain, they exhibit higher LAI in winter and early spring, and lower LAI in summer as compared to CTL. Significant LAI differences $(>0.8)$ mainly exist over eastern China and southern Asia in winter and early spring. Meanwhile, LAI changes are somewhat different in magnitude between sensitivity experiments. ReDVM and SiDVM simulate greener $(>0.2)$ surface than MODIS over some areas in winter and early spring due to a response to abnormal high temperature in 1998.

\subsection{Differences in Surface Air Temperature and Precipitation}

To evaluate model performance, station surface air temperature and precipitation data from the NCEP/CPC over land, and the CPC Merged Analysis of Precipitation (CMAP) data (Xie and Arkin 1997) over the ocean are aggregated onto the same spatial resolution as the model data. To accurately retain small-scale features resolved by observations, the multi-quadric interpolation method is adopted when interpolating station data to model grids (Nuss and Titley 1994).

Simulated surface air temperature in CTL is $3-7^{\circ} \mathrm{C}$ colder than the observations over many areas of China, Mongolia, Korea and Japan, and $1-5^{\circ} \mathrm{C}$ warmer than the observations over South Asia, and Northwest China and adjacent areas in winter and early spring (Fig. 3). The summer temperature is better simulated than winter and early spring, with the bias within $\pm 2^{\circ} \mathrm{C}$ of the observations. The changes introduced by MODIS LAI and vegetation interactions reduce or eliminate some temperature biases found in CTL in winter and early spring. In particular, the cold biases over Northeast China and adjacent areas, southern China, Korea and Japan are reduced, and the warm biases over South Asia are eliminated. In contrast LAI changes play a limited role in summer temperature simulations possibly because the percentage changes of summer LAI are relatively small. We also note that it is reasonably difficult to judge to what extent the biases are real or rather an artifact of incompatibility between observations and simulations over the Tibetan Plateau, partly because the low elevation bias of observational sites over mountainous terrain may render the observed temperatures higher than those from SNU-RCM.

The 1990s were the warmest decade on record, with the year 1998 the warmest year over Asia, accompanied by a large increase in vegetation greening and a longer growing season in Eurasia from 1981 to 1999 (Zhou et al. 2001). The vegetation interaction schemes allow vegetation to respond to temperature anomalies. High temperature in 1998 winter and early spring enhances vegetation growth, and leads to a greener land surface in ReDVM and SiDVM than in MODIS, which prescribes a 4-year climatologic LAI field. In turn, the greener surface feeds back to influence surface climate and atmospheric circulation, and introduces a higher tempera- 
ture over Northeast China and adjacent areas, southern China, Korea, and Japan, and a lower temperature in South Asia. These outcomes agree better with the observations.

Northeast China and adjacent areas, southern China and South Asia are three regions with large temperature responses, and we further examine the daily temperature differences throughout the whole year over the lands and these three regions (Fig. 4). MODIS LAI and vegetation interactions warm surface air temperature in February-to-April, which partly reduces temperature biases, but have a small impact in other months over the lands. The temperature biases over Northeast
China and adjacent areas are reduced all year round, while the improvement in South Asia and southern China mostly occurs in cold months. It is interesting to note that the impacts of LAI changes are different over different regions. For example, a greener land surface in cold months leads to an increase in temperature over Northeast China and adjacent areas and southern China, but a decrease over South Asia. The physical mechanisms leading to these differences will be discussed later. These differences also imply that MODIS LAI and vegetation interactions improve temperature simulations more at regional and local scales than on a continental basis.

MODIS - CTL
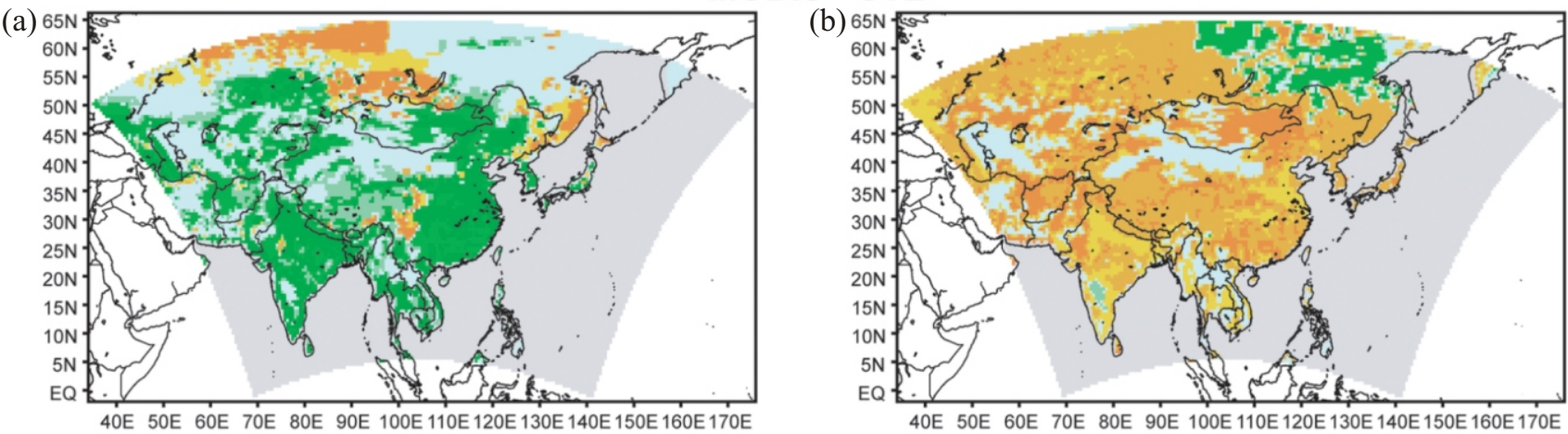

40E 50E 60E 70E 80E 90E 100E 110E 120E 130E 140E 150E 160E 170E

ReDVM - CTL

(c)

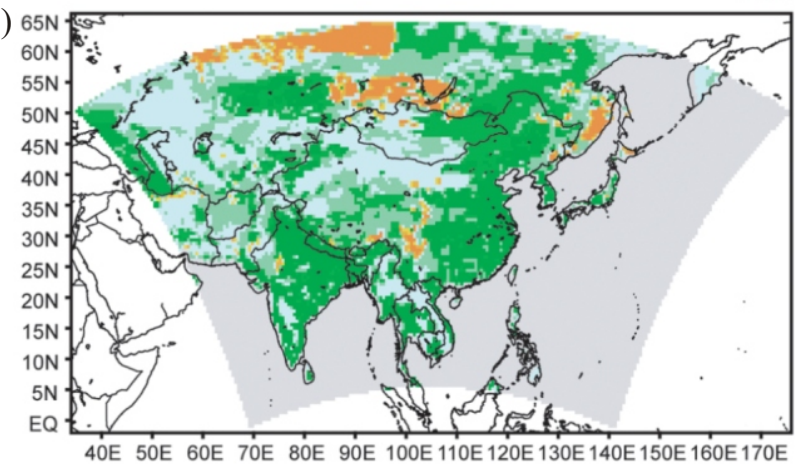

(d) $65 \mathrm{~N}$ tos

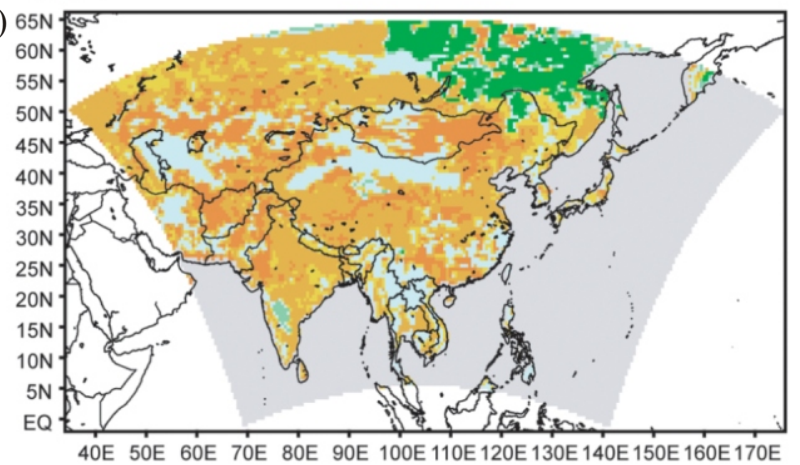

SiDVM - CTL

(e)

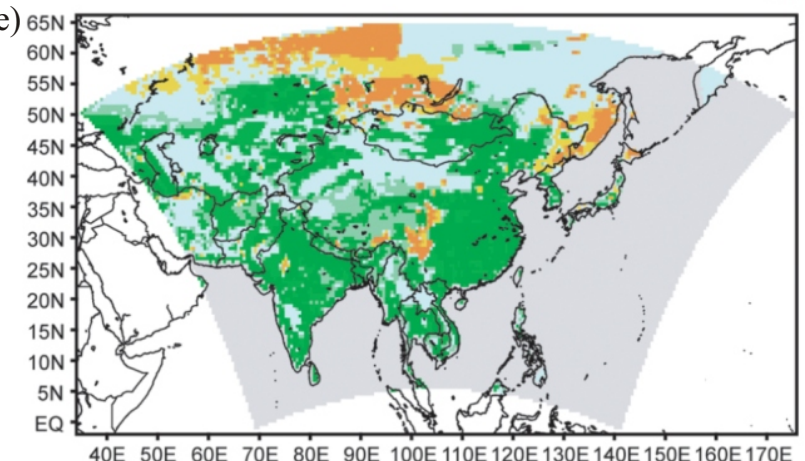

(f) $65 \mathrm{~N}$

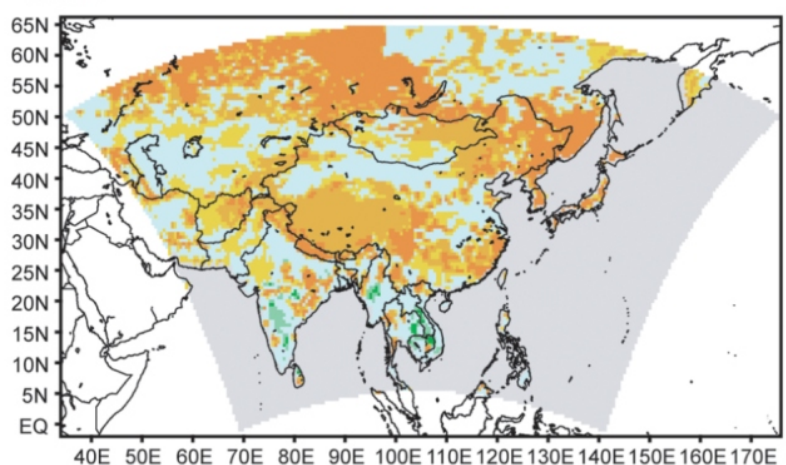

40E 50E 60E 70E 80E 90E 100E 110E 120E 130E 140E 150E 160E 170E

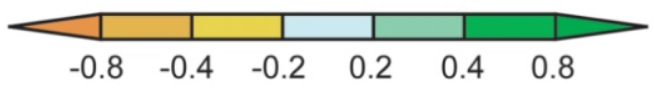

Fig. 2. LAI differences between MODIS, ReDVM, SiDVM and CTL in January-to-March (left panels) and June-to-August (right panels). 


\section{CTL - Observation}

(a) 60

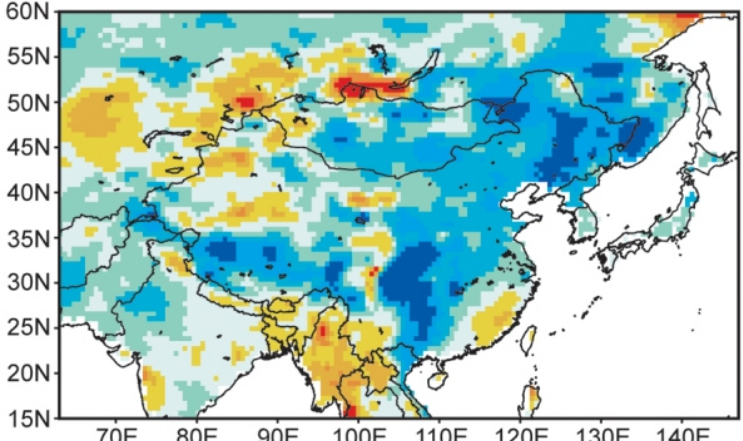

(b) 60

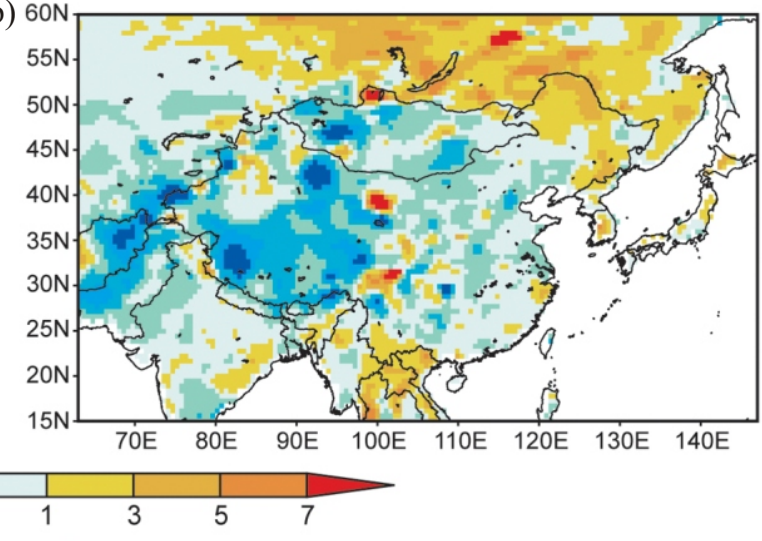

MODIS - CTL

(c)

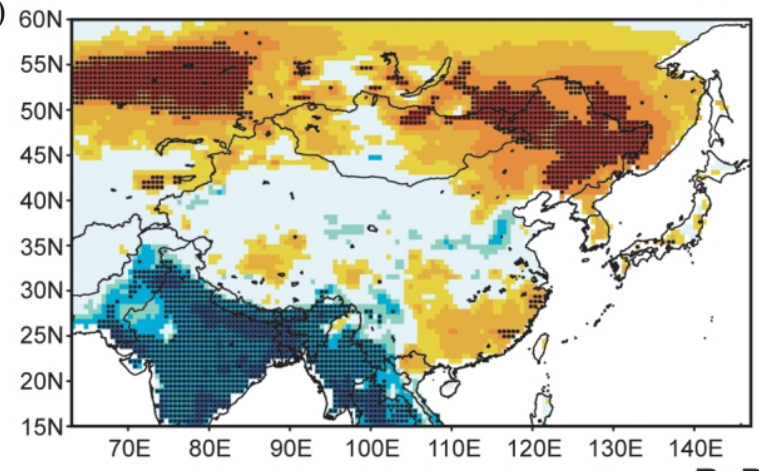

(d) 60

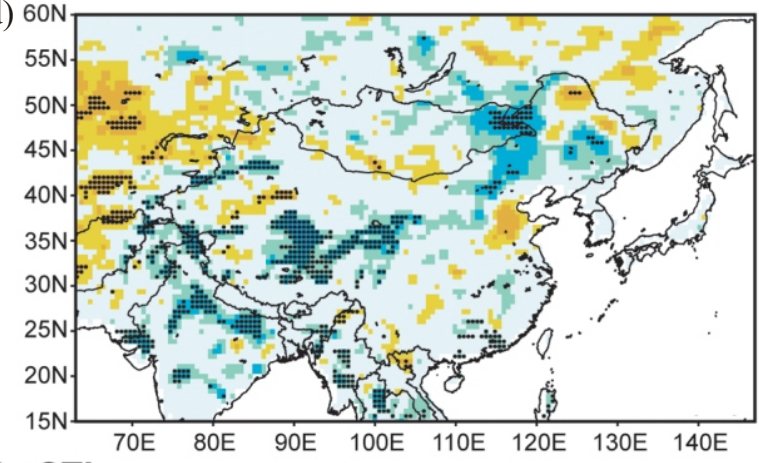

(e)

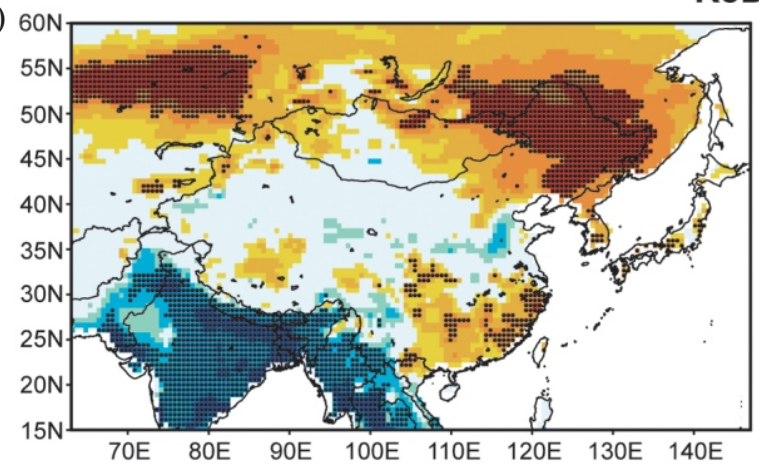

(f) $60 \mathrm{~N}$

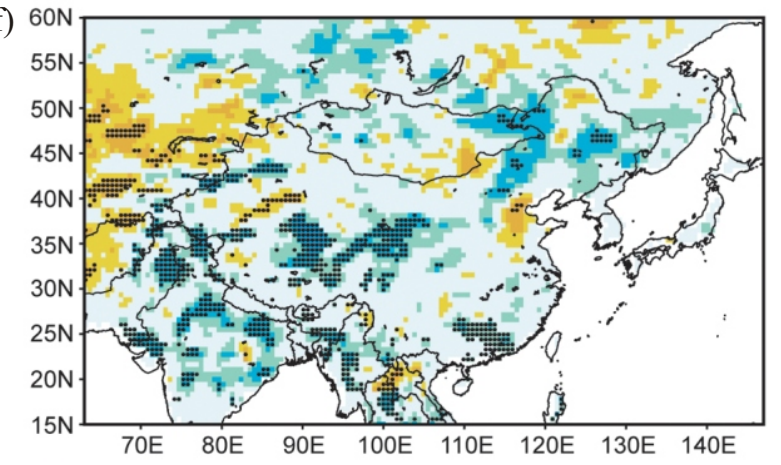

SIDVM - CTL

(g)

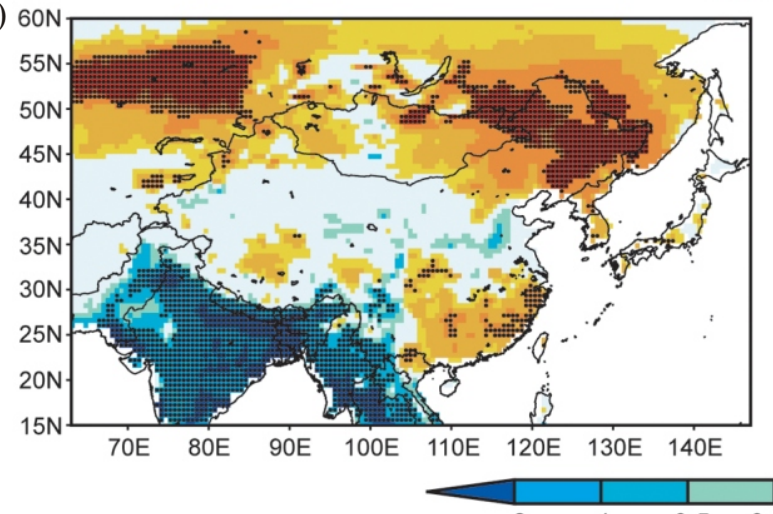

(h) 6

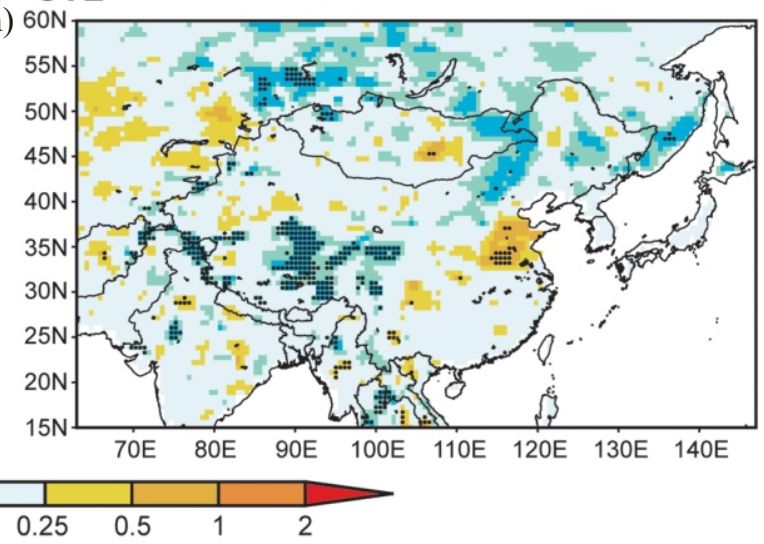

Fig. 3. Differences in surface air temperature (in ${ }^{\circ} \mathrm{C}$ ) between CTL and observations, and between MODIS, ReDVM, SiDVM and CTL in January-to-March (left panels) and June-to-August (right panels). The grid cells with values significant at $90 \%$ confidence level by Student's t-test are marked by closed circle. 

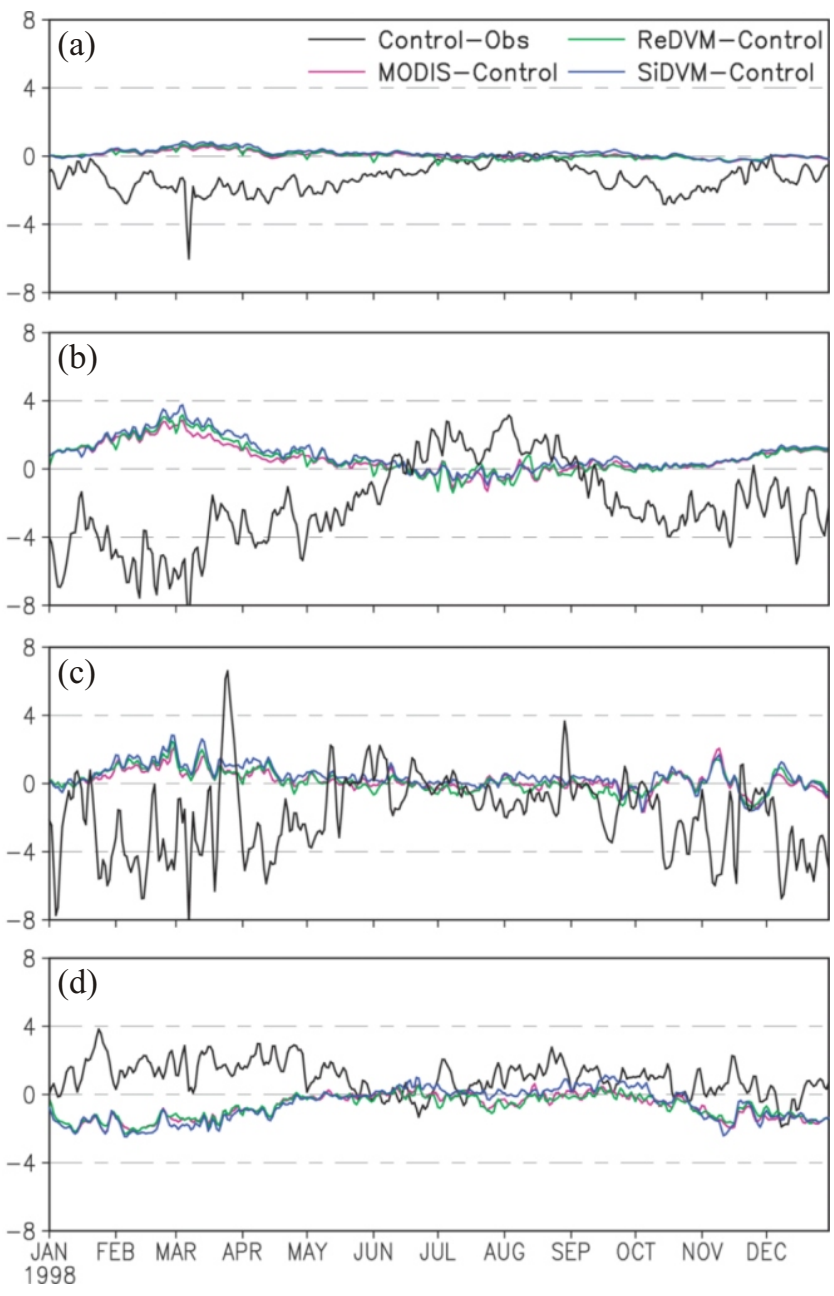

Fig. 4. Daily temperature differences (in ${ }^{\circ} \mathrm{C}$ ) averaged over: (a) the lands $\left(63-147^{\circ} \mathrm{E}, 15-60^{\circ} \mathrm{N}\right)$; (b) Northeast China and adjacent areas $\left(110-130^{\circ} \mathrm{E}, 40-55^{\circ} \mathrm{N}\right)$; (c) southern China $\left(105-120^{\circ} \mathrm{E}, 22-28^{\circ} \mathrm{N}\right)$; and (d) South Asia $\left(78-102^{\circ} \mathrm{E}, 20-25^{\circ} \mathrm{N}\right)$.

We subsequently look at precipitation differences (Fig. 5). In winter and early spring, the CTL simulates too much precipitation in a broad band extending from East China to the West Tibetan Plateau, too little precipitation in South Asia. Increased LAI decreases the precipitation over southern and northern China and the South Tibetan Plateau, and increases precipitation over South Asia, therefore reducing the precipitation discrepancies over these regions in MODIS, ReDVM, and SiDVM. In summer, the CTL produces too much precipitation over the arid to semi-arid band from Northeast China to West China, and too little precipitation over the areas north and south of this band. The MODIS and ReDVM simulate less precipitation over the arid to semiarid band, which is in better agreement with the observations. However, there is generally more spatial heterogeneity with respect to summer precipitation simulations than winter and early spring precipitation simulations. The changes are insignificant in most areas of the model domain, implying that there are larger uncertainties in summer precipitation differences induced by LAI changes.

These temperature and precipitation differences between experiments and divergences from observations are further evident in the analyses of regional means of winter and early spring surface air temperature and precipitation (Table 2). Consistent improvements in temperature simulations are seen over the lands and several hot spots when MODIS LAI and vegetation interaction schemes are implemented. Over the lands, greener land surface produces a mean temperature of about $-3.4^{\circ} \mathrm{C}$, about $0.3^{\circ} \mathrm{C}$ warmer than the CTL simulation. For specific regions, it warms Northeast China by 1.6 $1.9^{\circ} \mathrm{C}$ and southern China by $0.6-0.8^{\circ} \mathrm{C}$, and cools South Asia by about $1.5^{\circ} \mathrm{C}$. These changes are all in the direction of reducing temperature biases. Precipitation increases from 0.58 to about $0.7 \mathrm{~mm} \mathrm{day}^{-1}$ in South Asia, which is closer to the observation by an order of $0.93 \mathrm{~mm} \mathrm{day}^{-1}$. Also, the high precipitation bias of southern China is partly reduced, though it is still too large compared to the observation.

\subsection{Differences in Surface Energy Balance Components}

Since changes in each surface energy balance component (as well as circulation in section 3.4) exhibit a similar spatial distribution in MODIS, ReDVM, and SiDVM, we only present the difference field between MODIS and CTL in the following analysis. We focus our discussions on winter and early spring since differences in summer surface climate are less significant. Solar radiation drives surface energy balance by controlling surface available energy. LAI changes influence downward solar radiation mostly via clouds, and upward solar radiation via surface albedo. Meanwhile, LAI changes also modify the partitioning of surface available energy into sensible heat, latent heat, ground heat and snow melt heat. Figure 6 shows that net solar radiation changes are generally larger than net longwave radiation changes and dominate net radiation differences. Note that emitted longwave radiation, which depends on ground or skin temperature, dominates change in net longwave radiation. Its change tends to damp the response of surface air temperature to LAI change. There are significant changes in winter and early spring radiation and heat fluxes over several hot spots. Over northern Asia and southern China, sensible heat is in stronger response to the large increase in net solar radiation than latent heat, leading to increased surface air temperature. In contrast dramatically increased evapotranspiration cools surface air temperature over South Asia.

Tables 3, 4, 5, and 6 show regional mean differences of surface energy balance components and LAI in winter and early spring over the lands, Northeast China and adjacent areas, southern China, and South Asia, respectively. Over the lands, the dominant effects of increased LAI are a large decrease in upward solar radiation, associated with an increase in latent heat flux mainly contributed by increased 
(a)

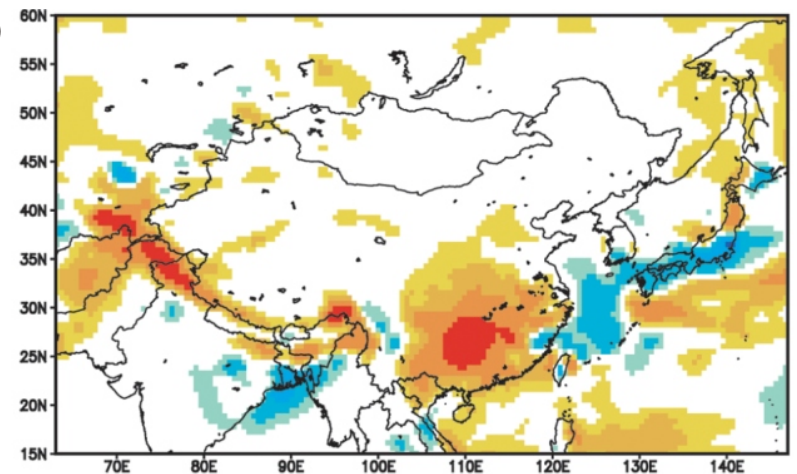

(b)

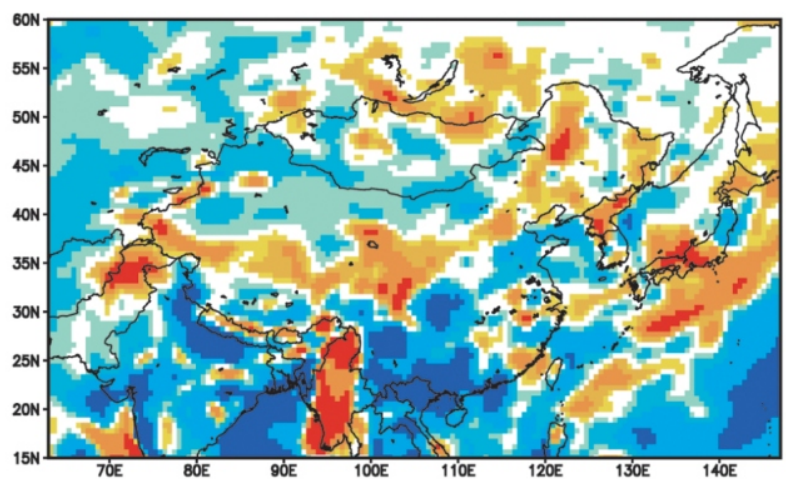

(c)

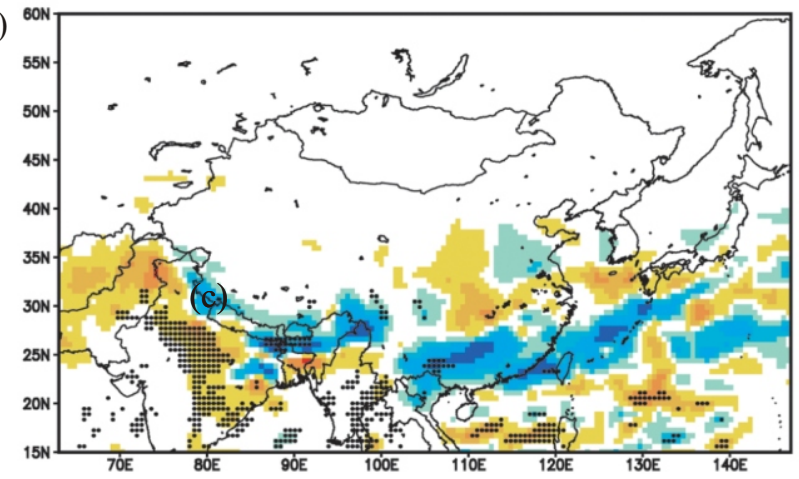

(e)

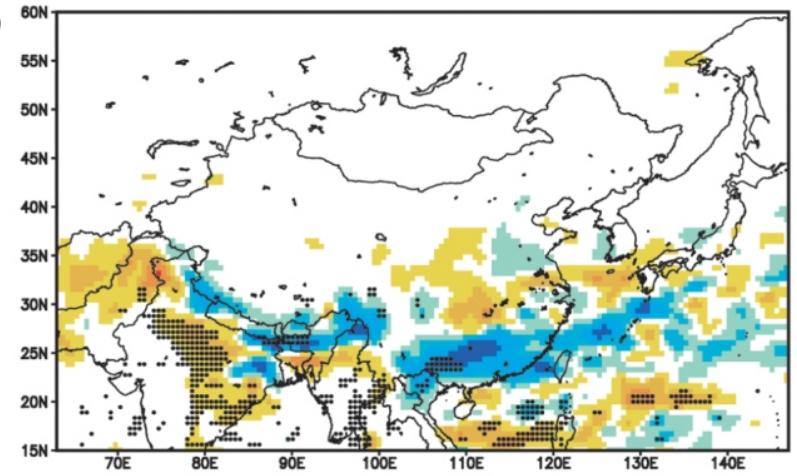

(d)

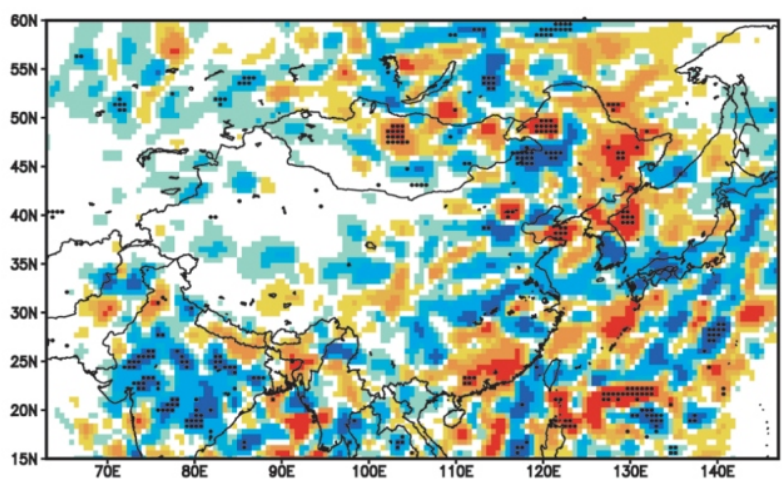

(f)

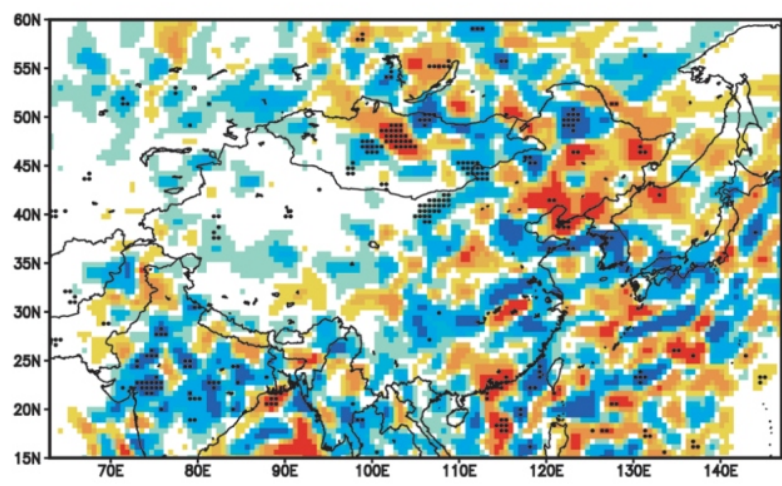

(h)
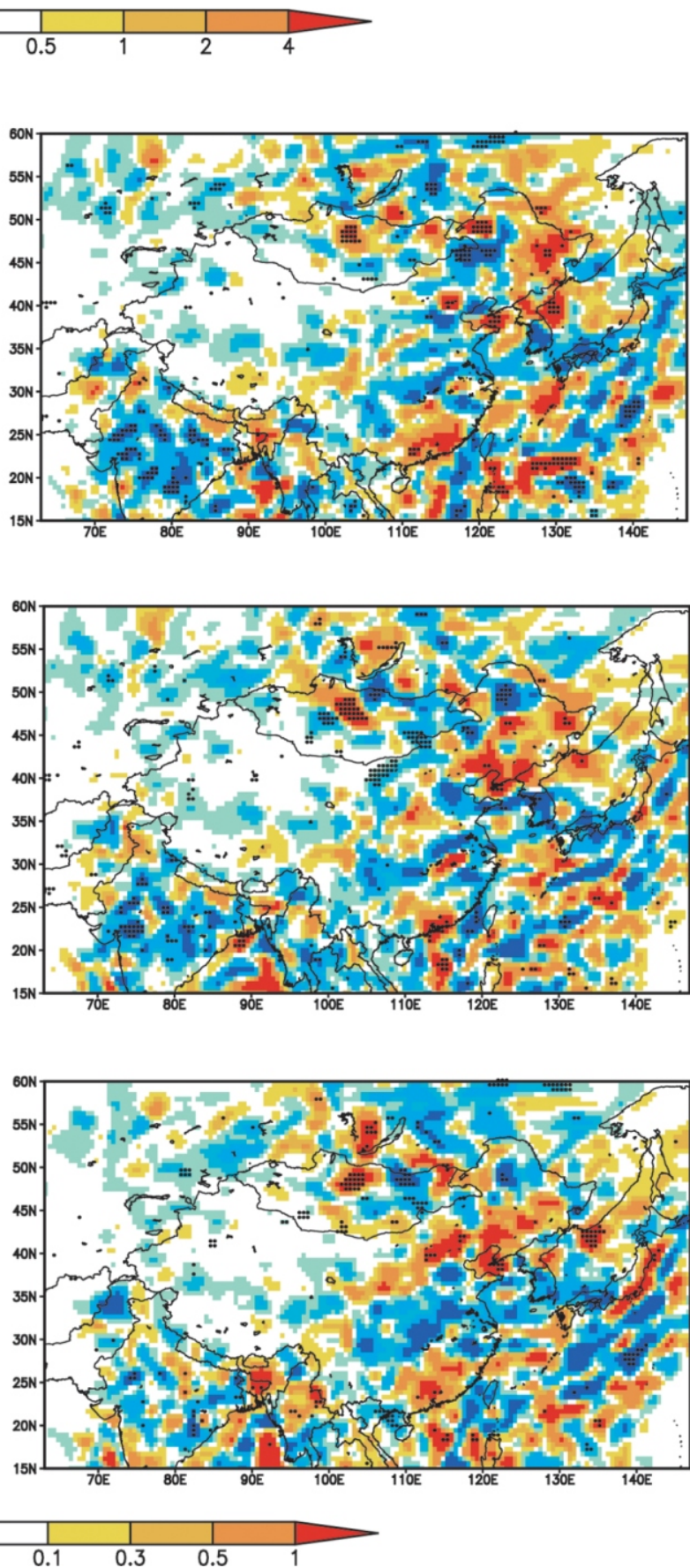

(g)

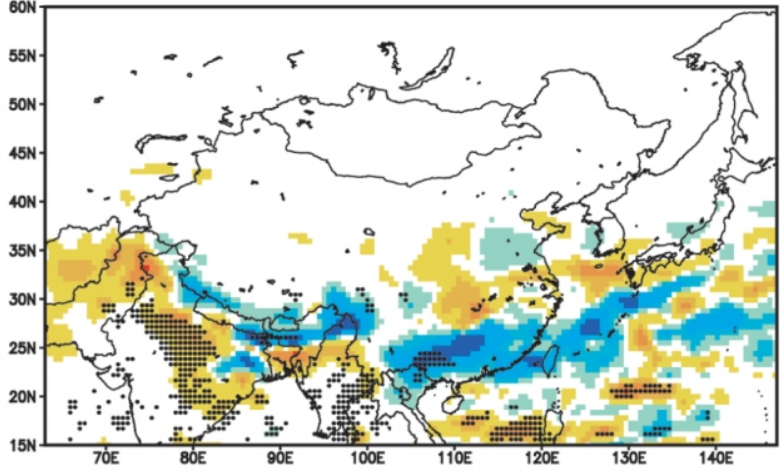

Fig. 5. Same as Fig. 3 but for precipitation (in mm day ${ }^{-1}$ ). 
Table 2. Regional mean January-to-March surface air temperature (in ${ }^{\circ} \mathrm{C}$ ) and precipitation (in $\mathrm{mm} \mathrm{d}^{-1}$ ) in observations and four experiments.

\begin{tabular}{lcccccc}
\hline \multicolumn{1}{c}{ Region } & Variable & Observation & CTL & MODIS & ReDVM & SiDVM \\
\hline \multirow{2}{*}{ Lands } & Precipitation & 0.58 & 1.09 & 1.08 & 1.08 & 1.08 \\
& Temperature & -2.04 & -3.70 & -3.44 & -3.39 & -3.43 \\
\multirow{3}{*}{ Northeast China } & Precipitation & 0.12 & 0.28 & 0.28 & 0.28 & 0.28 \\
& Temperature & -11.30 & -15.88 & -14.15 & -13.98 & -14.14 \\
\multirow{3}{*}{ Southern China } & Precipitation & 2.70 & 5.69 & 5.19 & 5.09 & 5.12 \\
& Temperature & 13.77 & 11.19 & 11.82 & 11.98 & 11.97 \\
\multirow{3}{*}{ South Asia } & Precipitation & 0.93 & 0.58 & 0.71 & 0.69 & 0.72 \\
& Temperature & 20.50 & 22.07 & 20.51 & 20.58 & 20.44 \\
\hline
\end{tabular}

(a)

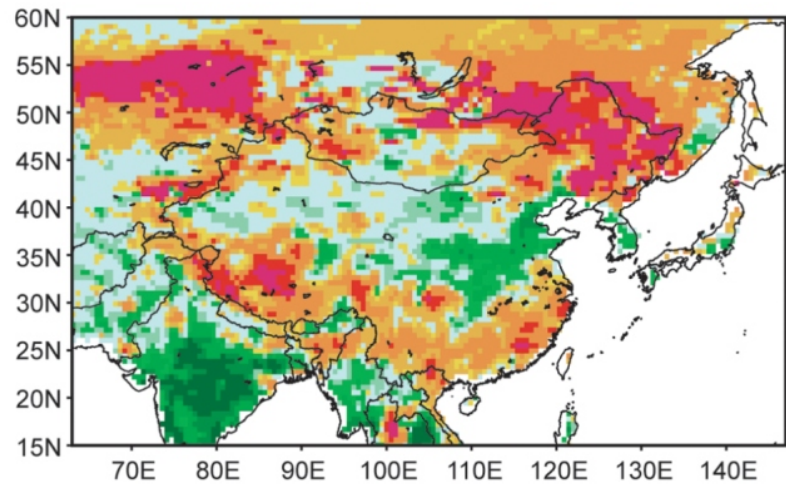

(c)

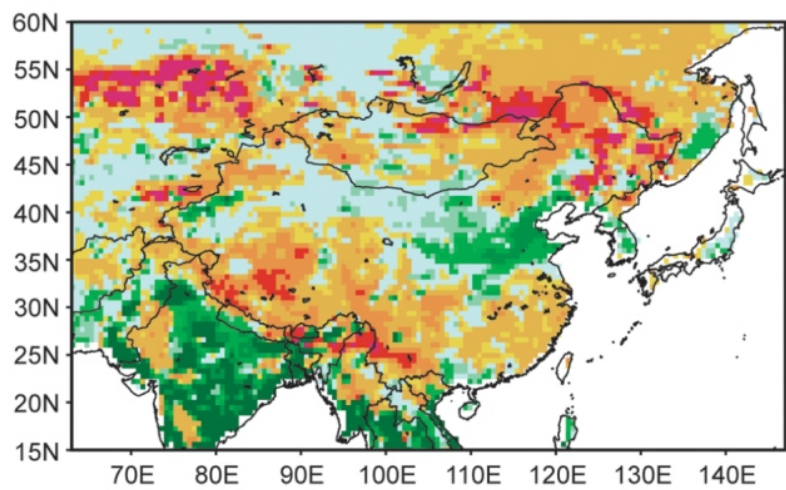

(e)

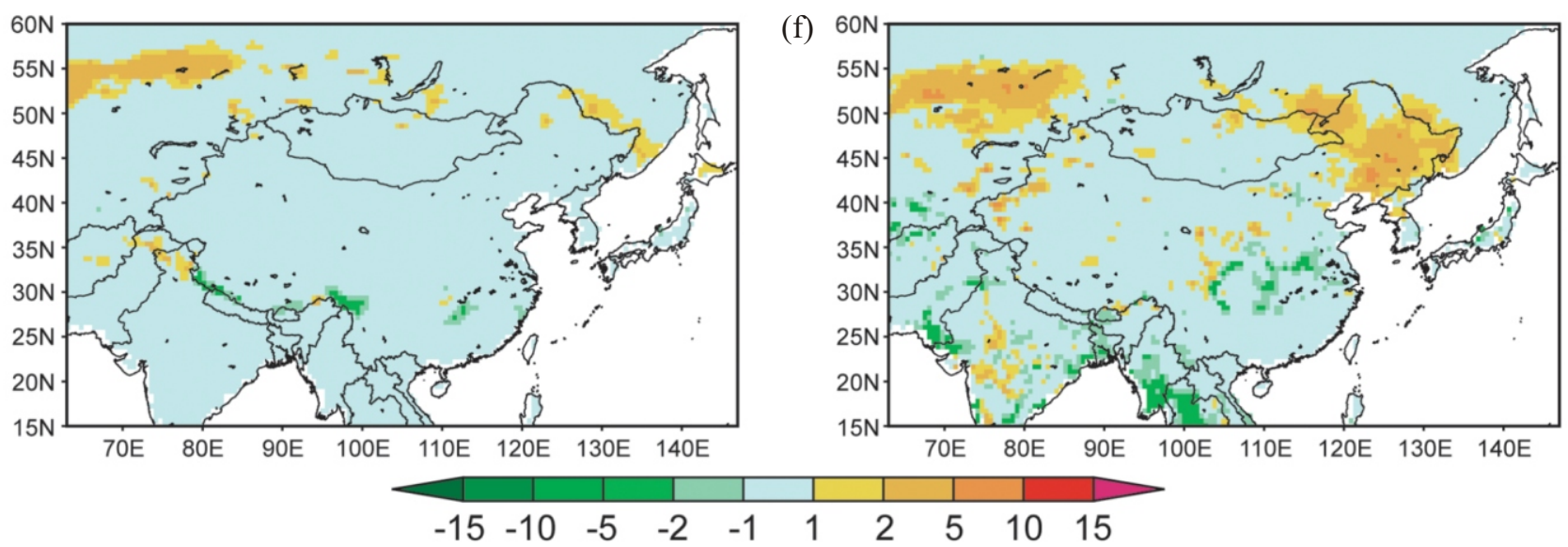

(b) $60 \mathrm{~N}$

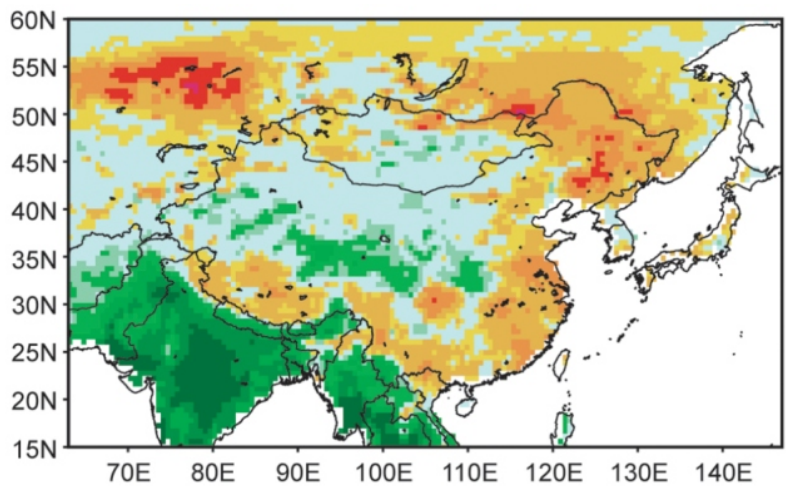

(d)

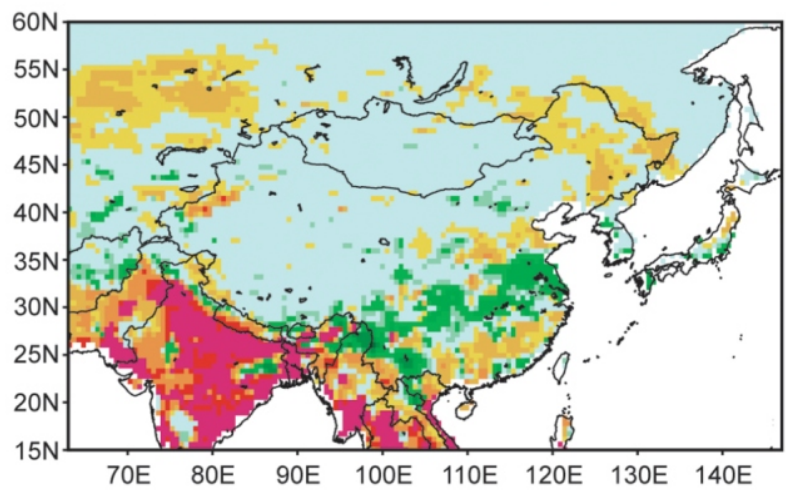

(i)

Fig. 6. Differences in January-to-March surface energy balance components (in $\mathrm{W} \mathrm{m}^{-2}$ ) between MODIS and CTL: (a) Net solar radiation; (b) Net longwave radiation; (c) sensible heat; (d) latent heat; (e) snow melt heat; and (f) ground heat. 
Table 3. Differences in January-to-March surface energy balance components (in $\left.\mathrm{W} \mathrm{m}{ }^{-2}\right)$ and LAI averaged over the lands $\left(15-60^{\circ} \mathrm{N}, 63-147^{\circ} \mathrm{E}\right)$.

\begin{tabular}{lcccccc}
\hline \multirow{2}{*}{ Variable } & \multicolumn{2}{c}{ MODIS-CTL } & \multicolumn{2}{c}{ ReDVM-CTL } & \multicolumn{2}{c}{ SiDVM-CTL } \\
\cline { 2 - 6 } & Difference & \%change & Difference & \%change & Difference & \%change \\
\hline LAI & +0.36 & 55.4 & +0.45 & 69.2 & +0.36 & 55.4 \\
Down solar radiation $\downarrow$ & -1.12 & -0.7 & -1.05 & -0.7 & -1.01 & -0.7 \\
Up solar radiation $\uparrow$ & -4.53 & -9.9 & -4.70 & -10.3 & -4.53 & -9.9 \\
Net solar radiation $\downarrow$ & +3.41 & 3.1 & +3.64 & 3.3 & +3.52 & 3.2 \\
Down longwave radiation $\downarrow$ & +1.29 & 0.6 & +1.29 & 0.6 & +1.22 & 0.5 \\
Up longwave radiation $\uparrow$ & +0.68 & 0.2 & +0.92 & 0.3 & +0.62 & 0.2 \\
Net longwave radiation $\uparrow$ & -0.61 & -0.8 & -0.37 & -0.5 & -0.60 & -0.8 \\
Net radiation $\downarrow$ & +4.02 & 11.9 & +4.01 & 11.0 & +4.12 & 11.8 \\
Sensible heat $\uparrow$ & -0.07 & -0.4 & -0.12 & -0.6 & -0.06 & -0.3 \\
Latent heat $\uparrow$ & +3.65 & 26.0 & +3.70 & 26.3 & +3.79 & 27.0 \\
Canopy transpiration $\uparrow$ & +3.50 & 137.8 & +3.50 & 137.8 & +3.60 & 141.7 \\
Canopy evaporation $\uparrow$ & +0.44 & 48.9 & +0.48 & 53.3 & +0.45 & 50 \\
Ground evaporation $\uparrow$ & -0.29 & -2.7 & -0.29 & -2.7 & -0.27 & -2.5 \\
Ground heat $\downarrow$ & +0.29 & 10.0 & +0.30 & 10.4 & +0.26 & 9.0 \\
Snow melt heat $\downarrow$ & +0.13 & 8.2 & +0.14 & 8.9 & +0.12 & 7.6 \\
\hline
\end{tabular}

Table 4. Same as Table 3 but for Northeast China and adjacent areas $\left(40-55^{\circ} \mathrm{N}, 110-130^{\circ} \mathrm{E}\right)$.

\begin{tabular}{lcccccc}
\hline \multirow{2}{*}{ Variable } & \multicolumn{2}{c}{ MODIS-CTL } & \multicolumn{2}{c}{ ReDVM-CTL } & \multicolumn{2}{c}{ SiDVM-CTL } \\
\cline { 2 - 6 } & Difference & \%change & Difference & \%change & Difference & \%change \\
\hline LAI & +0.41 & 60.3 & +0.59 & 86.8 & +0.39 & 57.4 \\
Down solar radiation & -3.24 & -2.3 & -3.49 & -2.5 & -3.26 & -2.3 \\
Up solar radiation & -15.11 & -26.2 & -16.03 & -27.8 & -15.11 & -26.2 \\
Net solar radiation & +11.87 & 14.5 & +12.54 & 15.3 & +11.85 & 14.5 \\
Down longwave radiation & +3.98 & 2.4 & +4.28 & 2.5 & +3.97 & 2.4 \\
Up longwave radiation & +7.64 & 3.1 & +8.20 & 3.3 & +7.67 & 3.1 \\
Net longwave radiation & +3.66 & 4.6 & +3.92 & 5.0 & +3.70 & 4.7 \\
Net radiation & +8.21 & 357.4 & +8.62 & 242.1 & +8.15 & 271.6 \\
Sensible heat & +5.93 & 116.3 & +6.07 & 119.0 & +5.90 & 115.7 \\
Latent heat & +0.70 & 14.0 & +0.82 & 16.4 & +0.68 & 13.6 \\
Canopy transpiration & +0.29 & 223.1 & +0.35 & 269.2 & +0.29 & 223.1 \\
Canopy evaporation & +0.25 & 53.2 & +0.27 & 57.4 & +0.24 & 51.1 \\
Ground evaporation & +0.16 & 3.6 & +0.20 & 4.5 & +0.15 & 3.4 \\
Ground heat & +1.44 & 17.0 & +1.56 & 18.4 & +1.42 & 16.7 \\
Snow melt heat & +0.13 & 10.5 & +0.16 & 12.9 & +0.13 & 10.5 \\
\hline
\end{tabular}


Table 5. Same as Table 3 but for southern China $\left(22-28^{\circ} \mathrm{N}, 105-120^{\circ} \mathrm{E}\right)$.

\begin{tabular}{lcccccc}
\hline \multirow{2}{*}{ Variable } & \multicolumn{2}{c}{ MODIS-CTL } & \multicolumn{2}{c}{ ReDVM-CTL } & \multicolumn{2}{c}{ SiDVM-CTL } \\
\cline { 2 - 7 } & Difference & \%Change & Difference & \%change & Difference & \%change \\
\hline LAI & +0.80 & 275.9 & +1.00 & 344.8 & +0.99 & 341.4 \\
Down solar radiation & +8.54 & 7.2 & +9.74 & 8.2 & +10.54 & 8.9 \\
Up solar radiation & +3.16 & 17.4 & +3.42 & 18.9 & +3.69 & 20.4 \\
Net solar radiation & +5.37 & 5.4 & +6.31 & 6.3 & +6.84 & 6.8 \\
Down longwave radiation & -0.48 & -0.1 & -0.85 & -0.2 & -0.80 & -0.2 \\
Up longwave radiation & +2.20 & 0.6 & +2.66 & 0.8 & +2.66 & 0.7 \\
Net longwave radiation & +2.68 & 8.1 & +3.51 & 10.6 & +3.46 & 10.5 \\
Net radiation & +2.69 & 4.1 & +2.80 & 4.2 & +3.38 & 5.0 \\
Sensible heat & +1.85 & 9.4 & +1.52 & 7.7 & +2.06 & 10.4 \\
Latent heat & +0.83 & 1.7 & +1.27 & 2.6 & +1.35 & 2.8 \\
Canopy transpiration & +6.18 & 309.0 & +7.04 & 352.0 & +7.52 & 376 \\
Canopy evaporation & +2.25 & 73.5 & +2.48 & 81.0 & +2.58 & 84 \\
Ground evaporation & -7.60 & -17.4 & -8.26 & -19.0 & -8.75 & -20.1 \\
Ground heat & +0.21 & 11.7 & +0.20 & 11.1 & +0.22 & 12.2 \\
Snow melt heat & -0.19 & -26.4 & -0.19 & -26.4 & -0.23 & -31.9 \\
\hline
\end{tabular}

Table 6. Same as Table 3 but for South Asia $\left(20-25^{\circ} \mathrm{N}, 78-102^{\circ} \mathrm{E}\right)$.

\begin{tabular}{lcccccc}
\hline \multirow{2}{*}{ Variable } & \multicolumn{2}{c}{ MODIS-CTL } & \multicolumn{2}{c}{ ReDVM-CTL } & \multicolumn{2}{c}{ SiDVM-CTL } \\
\cline { 2 - 6 } & Difference & \%change & Difference & \%change & Difference & \%change \\
\hline LAI & +0.63 & 40.1 & +0.74 & 47.1 & +0.63 & 40.1 \\
Down solar radiation & -2.54 & -1.1 & -2.15 & -0.9 & -2.35 & -1.0 \\
Up solar radiation & +3.15 & 9.7 & +3.19 & 9.8 & +3.13 & 9.6 \\
Net solar radiation & -5.69 & -2.8 & -5.34 & -2.6 & -5.48 & -2.7 \\
Down longwave radiation & -0.35 & -0.1 & -0.60 & -0.2 & -0.91 & -0.3 \\
Up longwave radiation & -10.38 & -2.4 & -9.91 & -2.3 & -11.02 & -2.5 \\
Net longwave radiation & -10.02 & -9.2 & -9.31 & -8.6 & -10.11 & -9.3 \\
Net radiation & +4.33 & 4.6 & +3.97 & 4.1 & +4.63 & 4.9 \\
Sensible heat & -9.28 & -4.0 & -9.75 & -14.7 & -9.82 & -14.8 \\
Latent heat & +14.17 & 51.2 & +14.35 & 51.8 & +15.12 & 54.6 \\
Canopy transpiration & +13.8 & 98.2 & +13.9 & 98.9 & +14.05 & 100 \\
Canopy evaporation & +0.38 & 61.3 & +0.40 & 64.5 & +0.41 & 66.1 \\
Ground evaporation & 0 & & +0.07 & 0.5 & +0.68 & 5.2 \\
Ground heat & -0.55 & -18.1 & -0.62 & -20.4 & -0.68 & -22.4 \\
Snow melt heat & 0 & & 0 & & 0 & \\
\hline
\end{tabular}


canopy transpiration over South Asia. These changes reflect that LAI alters surface energy balance mainly through the effects on surface albedo and stomatal conductance on a continental basis. However, the relative importance of the processes affected by LAI changes in influencing surface air temperature and precipitation is different between regions.

Northeast China and adjacent areas, which are mainly covered by cold grass and forest, have small LAI values and some snow cover in winter and early spring. As described by Buermann et al. (2001), the surface albedo of sparsely vegetated areas (LAI < 1) may be sensitive to LAI changes; the fraction of canopy covered by snow is directly influenced by LAI changes in snow-covered surface. Consequently, the increased LAI (> 60\%) reduces reflection and upward solar radiation with an excess of $15 \mathrm{~W} \mathrm{~m}^{-2}$, and then increases net radiation over Northeast China and adjacent areas (Table 4). On the other hand, LAI changes only result in a small increase in latent heat due to relatively low temperature. The increased radiation is largely partitioned into sensible heat with a mean increase of $>110 \%$. The cold biases are therefore reduced in this region.

A significant increase in downward solar radiation attributing to decreased cloud amount dominates the net radiation change over southern China (Table 5). The increased net radiation causes a larger increase in sensible heat than that in latent heat, therefore warming near-surface atmosphere and reducing the cold model bias. Although the change in latent heat is relatively small, the contribution of canopy transpiration, canopy evaporation and ground eva- poration is significantly different. With increased LAI, canopy transpiration and evaporation increase while ground evaporation decreases.

Over South Asia, increased canopy transpiration dominates changes in surface energy balance (Table 6). Consequently, less energy is partitioned into sensible heat, and surface air temperature is therefore cooled about $1.5^{\circ} \mathrm{C}$. Furthermore, the reduction of emitted longwave radiation is larger in magnitude than changes in solar radiation terms, and tends to damp the decrease in surface air temperature. Changes in surface albedo and clouds are found to play a limited role in surface energy balance difference. However, increased clouds bring more precipitation and help improve the precipitation bias.

\subsection{Circulation Changes}

LAI changes modify surface energy and water balance, and then atmospheric conditions through land-atmosphere interactions, which in turn influence surface climate and LAI. In winter and early spring when large-scale processes are important, precipitation and temperature differences are closely related to the responses of atmospheric moisture and circulation. To examine their changes, Figs. 7 and 8 present differences between MODIS and CTL in the 500-hPa geopotential height, and $850-\mathrm{hPa}$ wind vectors and mixing ratio, respectively. The anomalous anticyclone associated with the low geopotential height anomaly over South Asia provides favorable conditions for atmospheric moisture to be transported into this region. Together with increased local

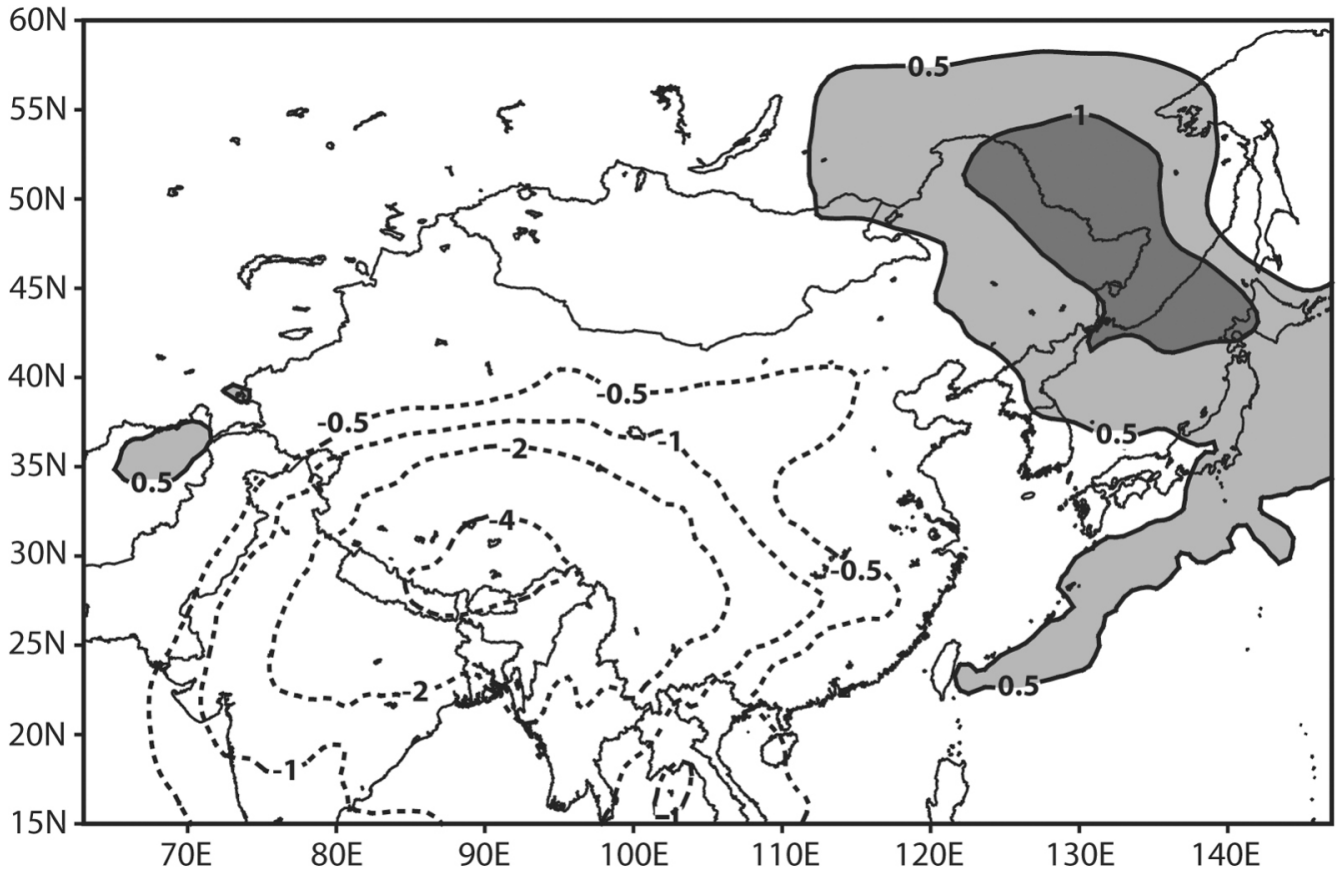

Fig. 7. Same as Fig. 6 but for 500-hPa geopotential height (in gpm). 


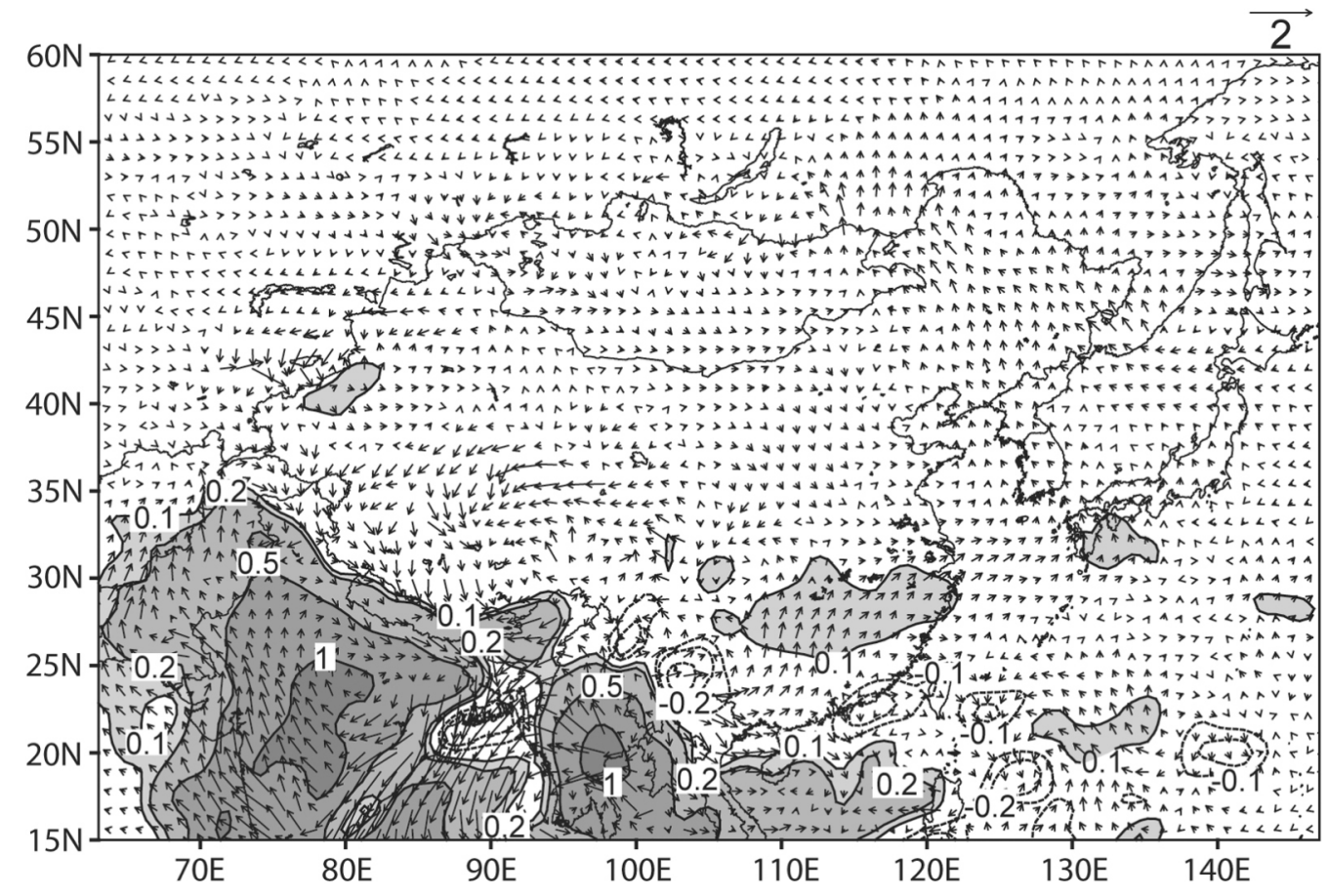

Fig. 8. Same as Fig. 6 but for 850 -hPa wind vectors (in $\mathrm{m} \mathrm{s}^{-1}$ ) and mixing ratio (in $\mathrm{g} \mathrm{kg}^{-1}$ ).

evapotranspiration, they enhance winter and early spring clouds and precipitation. In contrast, the mixing ratio drops over southern China mainly because the decrease in atmospheric moisture transported from the remote regions exceeds the increase in local evapotranspiration. Clouds and precipitation therefore decrease. Over Northeast China and adjacent areas, a higher geopotential height tends to slightly weaken the westerly, and therefore leads to a decrease in downward solar radiation through the effects on cloud amounts. However, the contribution of downward solar radiation change to differences in net radiation is relatively small as compared to change in upward solar radiation.

In summer, an important effect of decreased LAI is to dry the air over the arid to semi-arid band extending from Northeast China to West China, which reduces precipitation and therefore slightly improves the model performance. The anomalous cyclone and decreased atmospheric moisture tend to support a decrease in precipitation over this band (not shown).

\section{CONCLUSION AND DISCUSSION}

This study evaluates the role of the implementation of MODIS LAI and vegetation interaction schemes in regional climate simulations with the SNU-RCM. We focus on Asia, where the climate system is known to be extremely sensitive to ecological perturbations (Fu and Wen 1999).

The results show that MODIS LAI and vegetation interactions warm Northeast China and adjacent areas, Korea,
Japan and southern China, and reduce the temperature over South Asia in winter and early spring. Such differences in temperature, attributable to the higher LAI values of MODIS or predicted by vegetation dynamics, reduce or eliminate some model biases. The precipitation over southern China and South Asia is also better simulated in winter and early spring. Vegetation interactions are found to enhance temperature and precipitation simulations to a certain extent as compared to prescribed MODIS LAI. Possibly due to small percentage changes in LAI, the improvement in surface climate simulation is generally invisible in summer except for some areas.

Generally a change in LAI can modulate surface energy and water balances mainly via reflection and evapotranspiration, and then trigger responses of other physical and dynamical processes. However, the relative importance of these processes in winter and early spring is found to be different between regions. Surface warming of Northeast China and adjacent areas is mostly attributed to direct darkening effects of LAI on upward solar radiation. Increased LAI reduces the atmospheric moisture transferred into southern China relying on the effects on circulation. As a result, clouds and precipitation decrease. The reduction in clouds allows more solar radiation to reach the surface, and dominates the change in surface available energy. Subsequently, more sensible heat is released to warm near-surface atmosphere. Over South Asia, increased evapotranspiration is dominant in changes in surface energy balance, and enhances precipitation via the combined effects on lo- 
cal water recycling and atmospheric circulation. It also damps surface sensible heat exchange, and reduces surface air temperature.

The results of the study have implications for RCM simulation study of the Asian climate. Firstly, the study shows that the simulated near-surface climate is improved by the introduction of MODIS LAI, especially over several hotspots. This suggests a need to include a realistic description of plant phenology in current RCM simulations of Asian climate. Secondly, we provide two simple vegetation interaction schemes based on satellite observation to represent phonological variability of LAI. They show the usefulness in simulating the responses of LAI to seasonal variations in climate over Asia. Thirdly, observational evidence showed that northern vegetation generally increased with surface warming in recent decades (e.g., Zhou et al. 2001), and the two simple vegetation interaction schemes do simulate increased LAI on an annual, regional mean basis in response to abnormal high temperature during 1998 as compared to MODIS LAI climatology. This implies that the implementation of interactive vegetation in a RCM is important for dynamically downscaling global climate change projections.

Meanwhile, there are several limitations that leave room for further improvement. In this study we use the temperature to predict seasonal changes in LAI, but precipitation and radiation also have an important impact on vegetation activity over some areas of Asia (Nemani et al. 2003). The inclusion of these two important climate forcings in model representation of LAI phenology in a future study is expected to add value in simulating near-surface climate over some areas. Moreover, we focus on natural interactions between vegetation and climate. However, land use induced by human activities definitely regulates climate at a variety of timescales and is becoming a force of global importance (Foley et al. 2005). This issue deserves further investigation. Finally, there is generally more model uncertainty with regard to precipitation simulations than temperature simulations. One decade or longer simulations in the future may enable us to establish firmer conclusions regarding LAI effects on precipitation.

Nevertheless, our results illustrate the substantial role of accurate treatment of vegetation parameters in simulating Asian climate, and the potential benefits of vegetation interaction in improving seasonal temperature and precipitation forecasts. This suggests that improved monitoring of vegetation, soil moisture, and land surface fluxes over Asia is highly desirable in the future.

Acknowledgements The first author would like to thank Jiangfeng Wei at Center for Ocean-Land-Atmosphere Studies (COLA) for his valuable discussions. Insightful comments and suggestions by anonymous reviewers are appreciated. These substantially improved the earlier version of this manuscript. Jingyong Zhang worked at Seoul National University as a visiting scholar from June 2004 to January 2005. This study was supported by the Korea Meteorological Administration Research and Development Program under Grant CATER 2006-2303.

\section{REFERENCES}

Anthes, R. A., 1977: A cumulus parameterization scheme utilizing a one-dimensional cloud model. Mon. Wea. Rev., 105, 270-286, doi: 10.1175/1520-0493(1977)105<0270: ACPSUA $>2.0 . C O ; 2$. [Link $]$

Arora, V. K. and G. J. Boer, 2006: Simulating competition and coexistence between plant functional types in a dynamic vegetation model. Earth Interact., 10, 1-30, doi: 10.1175/ EI170.1. [Link]

Bonan, G. B., 1996: A land surface model (LSM version 1.0) for ecological, hydrological, and atmospheric studies: Technical descriptions and user guide, NCAR Technical Note NCAR/TN-417+STR, National Center for Atmospheric Research, Boulder, Colorado, 150 pp.

Bonan, G. B., S. Levis, S. Sitch, M. Vertenstein, and K. W. Oleson, 2003: A dynamic global vegetation model for use with climate models: concepts and description of simulated vegetation dynamics. Global Change Biol., 9, 15431566, doi: 10.1046/j.1365-2486.2003.00681.x. [Link]

Briegleb, B. P., 1992: Delta-Eddington approximation for solar radiation in the NCAR community climate model. J. Geophys. Res., 97, 7603-7612.

Buermann, W., J. R. Dong, X. B. Zeng, R. B. Myneni, and R. E. Dickinson, 2001: Evaluation of the utility of satellite-based vegetation leaf area index data for climate simulations. $J$. Climate, 14, 3536-3550, doi: 10.1175/1520-0442(2001) 014<3536:EOTUOS $>2.0 . C O ; 2$. [Link]

Chase, T. N., R. A. Pielke, T. G. F. Kittel, R. Nemani, and S. W. Running, 1996: Sensitivity of a general circulation model to global changes in leaf area index. J. Geophys. Res., 101, 7393-7408, doi: 10.1029/95JD02417. [Link]

Chen, M., D. Pollard, and E. J. Barron, 2004: Regional climate change in East Asia simulated by an interactive atmosphere-soil-vegetation model. J. Climate, 17, 557-572, doi: 10.1175/1520-0442(2004)017<0557:RCCIEA >2.0.CO;2. [Link]

Delire, C., S. L. Levis, G. Bonan, J. A. Foley, M. T. Coe, and S. Vavrus, 2002: Comparison of the climate simulated by the CCM3 coupled to two different land-surface models. Climate Dyn., 19, 657-669, doi: 10.1007/s00382-002-0255-7. [Link]

Delire, C., J. A. Foley, and S. Thompson, 2004: Long-term variability in a coupled atmosphere-Biosphere model. $J$. Climate, 17, 3947-3959, doi: 10.1175/1520-0442(2004) 017<3947:LVIACA>2.0.CO;2. [Link]

Dickinson, R. E., A. Henderson-Sellers, and P. J. Kennedy, 1993: Biosphere-Atmosphere Transfer Scheme (BATS) Version 1e as coupled to the NCAR Community Climate 
Model, NCAR Technical Note NCAR/TN-383+STR, National Center for Atmospheric Research, Boulder, Colorado, $72 \mathrm{pp}$.

Ding, Y., X. Shi, Y. Liu, Y. Liu, Q. Li, Y. Qian, M. Miao, G. Zhai, and K. Gao, 2006: Multi-year simulations and experimental seasonal predictions for rainy seasons in China by using a nested regional climate model (RegCM_NCC). Part I: Sensitivity study. Adv. Atmos. Sci., 23, 323-341, doi: 10.1007/s00376-006-0323-8. [Link]

Dudhia, J., 1989: Numerical study of convection observed during the winter monsoon experiment using a mesoscale two-dimesional model. J. Atmos. Sci., 46, 3077-3107, doi: 10.1175/1520-0469(1989)046<3077:NSOCOD>2.0.CO;2. [Link]

Foley, J. A., C. I. Prentice, N. Ramankutty, S. Levis, D. Pollard, S. Sitch, and A. Haxeltine, 1996: An integrated biosphere model of land surface processes, terrestrial carbon balance, and vegetation dynamics. Global Biogeochem. Cycles, 10, 603-628, doi: 10.1029/96GB02692. [Link]

Foley, J. A., S. Levis, I. C. Prentice, D. Pollard, and S. L. Thompson, 1998: Coupling dynamic models of climate and vegetation. Global Change Biol., 4, 561-579, doi: 10.1046/j.1365-2486.1998.t01-1-00168.x. [Link]

Foley, J. A., R. DeFries, G. P. Asner, C. Barford, G. Bonan, S. R. Carpenter, F. S. Chapin, M. T. Coe, G. C. Daily, H. K. Gibbs, J. H. Helkowski, T. Holloway, E. A. Howard, C. J. Kucharik, C. Monfreda, J. A. Patz, I. C. Prentice, N. Ramankutty, and P. K. Snyder, 2005: Global consequences of land use. Science, 309, 570-574, doi: 10.1126/science. 1111772. [Link]

Fu, C. B. and G. Wen, 1999: Variation of ecosystem over East Asia in association with seasonal, interannual and decadal monsoon climate variability. Clim. Change, 43, 477-494, doi: 10.1023/A:1005471600483. [Link]

Fu, C. B., S. Wang, Z. Xiong, W. J. Gutowski, D. K. Lee, J. L. McGregor, Y. Sato, H. Kato, J. W. Kim, and M. S. Suh, 2005: Regional climate model intercomparison project for Asia. Bull. Amer. Meteor. Soc., 86, 257-266, doi: 10.1175/ BAMS-86-2-257. [Link]

Grell, A. G., J. Dudhia, and D. R. Stauffer, 1994: A description of the fifth-generation Penn State/NCAR mesoscale model (MM5), NCAR Technical Note NCAR/TN398+STR, National Center for Atmospheric Research, Boulder, Colorado, $117 \mathrm{pp}$.

Haxeltine, A. and I. C. Prentice, 1996: BIOME3: An equilibrium terrestrial biosphere model based on ecophysiological constraints, resource availability, and competition among plant functional types. Global Biogeochem. Cycles, 10, 693-709, doi: 10.1029/96GB02344. [Link]

Hong, S. Y. and H. L. Pan, 1996: Nonlocal boundary layer vertical diffusion in a medium range forecast model. Mon. Wea. Rev., 124, 2322-2339, doi: 10.1175/1520-0493(1996) 124<2322:NBLVDI $>2.0 . \mathrm{CO} ; 2$. [Link]

Kang, H. S., D. H. Cha, and D. K. Lee, 2005: Evaluation of the mesoscale model/land surface model (MM5/LSM) cou- pled model for East Asian summer monsoon simulations. J. Geophys. Res., 110, D10105, doi: 10.1029/2004JD 005266. [Link]

Kaufmann, R. K., L. Zhou, R. B. Myneni, C. J. Tucker, D. Slayback, N. V. Shabanov, and J. Pinzon, 2003: The effect of vegetation on surface temperature: A statistical analysis of NDVI and climate data. Geophys. Res. Lett., 30, 2147, doi: 10.1029/2003GL018251. [Link]

Kistler, R., E. Kalnay, W. Collins, S. Saha, G. White, J. Woollen, M. Chelliah, W. Ebisuzaki, M. Kanamitsu, V. Kousky, H. v. d. Dool, R. Jenne, and M. Fiorino, 2001: The NCEP/ NCAR 50-year reanalysis: Monthly means CD-ROM and documentation. Bull. Amer. Meteor. Soc., 82, 247-267, doi: 10.1175/1520-0477(2001)082<0247:TNNYRM>2.3. CO;2. [Link]

Knyazikhin, Y., J. V. Martonchik, R. B. Myneni, D. J. Diner, and S. W. Running, 1998: Synergistic algorithm for estimating vegetation canopy leaf area index and fraction of absorbed photosynthetically active radiation from MODIS and MISR data. J. Geophys. Res., 103, 32257-32275, doi: 10.1029/98JD02462. [Link]

Lee, D. K., H. S. Kang, and K. H. Min, 2002: The role of ocean roughness in regional climate modeling: 1994 East Asian summer monsoon case. J. Meteor. Soc. Japan, 80, 171189, doi: 10.2151/jmsj.80.171. [Link]

Lee, D. K., D. H. Cha, and H. S. Kang, 2004: Regional climate simulation of the 1998 summer flood over East Asia. $J$. Meteor. Soc. Japan, 82, 1735-1753, doi: 10.2151/jmsj.82. 1735. [Link]

Leung, L. R., S. J. Ghan, Z. C. Zhao, Y. Luo, W. C. Wang, and H. Wei, 1999: Intercomparison of regional climate simulations of the 1991 summer monsoon in East Asia. J. Geophys. Res., 104, 6425-6454, doi: 10.1029/1998JD200016. [Link]

Levis, S. and G. B. Bonan, 2004: Simulating springtime temperature patterns in the community atmosphere model coupled to the community land model using prognostic leaf area. J. Climate, 17, 4531-4540, doi: 10.1175/3218.1. [Link]

Liang, X. Z., K. E. Kunkel, and A. N. Samel, 2001: Development of a Regional Climate Model for U.S. Midwest applications. Part I: Sensitivity to buffer zone treatment. $J$. Climate, 14, 4363-4378, doi: 10.1175/1520-0442(2001) 014<4363:DOARCM>2.0.CO;2. [Link]

Liu, Z. Y., M. Notaro, J. Kutzbach, and N. Liu, 2006: Assessing global vegetation-climate feedbacks from observations. $J$. Climate, 19, 787-814, doi: 10.1175/JCLI3658.1. [Link]

Lu, L., R. A. Pielke, Sr., G. E. Liston, W. Parton, D. Ojima, and M. Hartman, 2001: Implementation of a two-way Interactive Atmospheric and Ecological Model and its Application to the Central United States. J. Climate, 14, 900-919, doi: 10.1175/1520-0442(2001)014<0900:IOATWI >2.0. CO;2. [Link]

Lüdeke, M. K. B., F. W. Badeck, R. D. Otto, C. Hager, S. Dönges, J. Kindermann, G. Würth, T. Lang, U. Jäkel, A. Klaudius, P. Ramge, S. Habermehl, and G. H. Kohlmaier, 
1994: The Frankfurt Biosphere Model: A global process oriented model of seasonal and long-term $\mathrm{CO}_{2}$ exchange between terrestrial ecosystems and the atmosphere, I: Model description and illustrative results for cold deciduous and boreal forests. Clim. Res., 4, 143-166, doi: 10.3354/ cr004143. [Link]

Maynard, K. and J. F. Royer, 2004: Sensitivity of a general circulation model to land surface parameters in African tropical deforestation experiments. Climate Dyn., 22, 555572, doi: 10.1007/s00382-004-0398-9. [Link]

Myneni, R. B., S. Hoffman, Y. Knyazikhin, J. L. Privette, J. Glassy, Y. Tian, Y. Wang, X. Song, Y. Zhang, G. R. Smith, A. Lotsch, M. Friedl, J. T. Morisette, P. Votava, R. R. Nemani, and S. W. Running, 2002: Global products of vegetation leaf area and fraction absorbed PAR from year one of MODIS data. Remote Sens. Environ., 83, 24-231, doi: 10.1016/S0034-4257(02)00074-3. [Link]

Nemani, R. R., C. D. Keeling, H. Hashimoto, W. M. Jolly, S. C. Piper, C. J. Tucker, R. B. Myneni, and S. W. Running, 2003: Climate-driven increases in global terrestrial net primary production from 1982 to 1999. Science, 300, 1560-1563, doi: 10.1126/science.1082750. [Link]

Nuss, W. A. and D. W. Titley, 1994: Use of multiquadric interpolation for meteorological objective analysis. Mon. Wea. Rev., 122, 1611-1631, doi: 10.1175/1520-0493(1994)122 $<$ 1611:UOMIFM>2.0.CO;2. [Link]

Smith, T. M. and R. W., Reynolds, 1998: A high-resolution global sea surface temperature climatology for the 196190 base period. J. Climate, 11, 3320-3323, doi: 10.1175/ 1520-0442(1998)011<3320:AHRGSS>2.0.CO;2. [Link]

Texier, D., N. De Noblet, S. P. Harrison, A. Haxeltine, D. Jolly, S. Joussaume, F. Laarif, I. C. Prentice, and P. Tarasov, 1997: Quantifying the role of biosphere-atmosphere feedbacks in climate change: Coupled model simulations for $6000 \mathrm{BP}$ and comparisons with palaeodata for northern Eurasia and northern Africa. Climate Dyn., 13, 865-881, doi: 10.1007/s003820050202. [Link]

Tian, Y., R. E. Dickinson, L. Zhou, X. Zeng, Y. Dai, R. B. Myneni, Y. Knyazikhin, X. Zhang, M. Friedl, H. Yu, W. $\mathrm{Wu}$, and M. Shaikh, 2004: Comparison of seasonal and spatial variations of leaf area index and fraction of absorbed photosynthetically active radiation from Moderate Resolution Imaging Spectroradiometer (MODIS) and common Land Model. J. Geophys. Res., 109, D01103, doi: 10.1029/2003JD003777. [Link]

Tsvetsinskaya, E. A., L. O. Mearns, and W. E. Easterling, 2001: Investigating the effect of seasonal plant growth and development in three-dimensional atmospheric simulations. Part I: Simulation of surface fluxes over the growing sea- son. J. Climate, 14, 692-709, doi: 10.1175/1520-0442 (2001)014<0692:ITEOSP>2.0.CO;2. [Link]

Wang, G. L. and E. A. B. Eltahir, 2000: Role of vegetation dynamics in enhancing the low-frequency variability of the Sahel rainfall. Water Resour. Res., 36, 1013-1021, doi: 10.1029/1999WR900361. [Link]

Wang, W., B. T. Anderson, N. Phillips, and R. K. Kaufmann, 2006: Feedbacks of vegetation on summertime climate variability over the North American grasslands. Part I: Statistical analysis. Earth Interact., 10, Paper 10-017, 1-27.

Wang, Y., O. L. Sen, and B. Wang, 2003: A highly resolved regional climate model (IPRC-RegCM) and its simulation of the 1998 severe precipitation event over China. Part I: Model description and verification of simulation. J. Climate, 16, 1721-1738, doi: 10.1175/1520-0442(2003)016 $<1721$ :AHRRCM>2.0.CO;2. [Link]

Willmott, C. J. and K. Matsuura, 1995: Smart interpolation of annually averaged air temperature in the United States. $J$. Appl. Meteorol., 34, 2577-2586, doi: 10.1175/1520-0450 (1995)034<2577:SIOAAA >2.0.CO;2. [Link]

Xie, P. and P. A. Arkin, 1997: Global Precipitation: A 17-year monthly analysis based on gauge observations, satellite estimates, and numerical model outputs. Bull. Amer. Meteor. Soc., 78, 2539-2558, doi: 10.1175/1520-0477(1997) 078<2539:GPAYMA>2.0.CO;2. [Link]

Yang, W., N. V. Shabanov, D. Huang, W. Wang, R. E. Dickinson, R. R. Nemani, Y. Knyazikhin, and R. B. Myneni, 2006: Analysis of leaf area index products from combination of MODIS Terra and Aqua data. Remote Sens. Environ., 104, 297-312, doi: 10.1016/j.rse.2006.04.016. [Link]

Zeng, N., J. D. Neelin, K. M. Lau, and C. J. Tucker, 1999: Enhancement of interdecadal climate variability in the Sahel by vegetation interaction. Science, 286, 1537-1540, doi: 10.1126/science.286.5444.1537. [Link]

Zhang, J. Y., W. J. Dong, C. B. Fu, and L. Y. Wu, 2003: The influence of vegetation cover on summer precipitation in China: A statistical analysis of NDVI and climate data. Adv. Atmos. Sci., 1002-1006, doi: 10.1007/BF02915523. [Link]

Zhang, J. Y., W. C. Wang, and J. Wei, 2008: Assessing landatmosphere coupling using soil moisture from the Global Land Data Assimilation System and observational precipitation. J. Geophys. Res., 113, D17119, doi: 10.1029/ 2008JD009807. [Link]

Zhou, L., C. J. Tucker, R. K. Kaufmann, D. Slayback, N. V. Shabanov, and R. B. Myneni, 2001: Variations in northern vegetation activity inferred from satellite data of vegetation index during 1981 to 1999. J. Geophys. Res., 106, 20069-20083, doi: 10.1029/2000JD000115. [Link] 